\title{
Mercury (II) Nitrate $\left(\mathrm{Hg}\left(\mathrm{NO}_{3}\right)_{2}\right)$ : Interaksi Molekul dan Adsorpsi Hg dengan Karbon Aktif
}

\author{
Intan Prima Delvi), Rahadian Zainul ${ }^{2}$ \\ Chemistry Laboratorium, FMIPA, Universitas Negeri Padang, Indonesia \\ Physical Chemistry Laboratory, FMIPA, Universitas Negeri Padang, Indonesia \\ Enviroment Chemestry Laboratory, FMIPA, Universitas Negeri Padang, Indonesia \\ *E-mail: primadelvi@gmail.com
}

\begin{abstract}
Abstrak. Raksa (II) Nitrat merupakan suatu senyawa berupa kristal yang tak berwarna atau bewarna putih. Senyawa ini dapat dibuat dengan bereaksikan asam nitrat dengan logam raksa. Raksa dapat larut di dalam air dalam bentuk senyawa raksa (II) Nitrat ini. Selain itu juga dapat larut dalam aseton, amoniak, namun tidak dapat larut dalam alkohol. Tujuan penulisan ini yaitu untuk mengetahui pergerakan molekul $\mathrm{Hg}\left(\mathrm{NO}_{3}\right)_{2}$ Metode yang digunakan pada preview ini adalah perhitungan secara matematis pada besaran mobilitas ion dan konduktivitas termal, studi literatur menggunakan Endnote X7, dan penggambaran molekul dengan menggunakan aplikasi ChemOffice Proffesional versi 15.0. Proses menganalisis data yaitu dengan menghitung MM2 dari molekul $\mathrm{Hg}\left(\mathrm{NO}_{3}\right)_{2}$ yang terdiri dari MM2 minimization, MM2 dynamic, dan MM2 properties. Penulisan ini juga bertujuan untuk mengetahui teknik pemisahan $\mathrm{Hg}$ pada limbah pabrik dengan proses adsorbsi dengan karbon aktif dengan meriview beberapa jurnal penelitian yang sudah ada. Adsorpsi fisika adalah proses terkonsentrasinya molekul-molekul adsorbet( molekul yang diadsorpsi) dalam air ke permukaan karbon aktif. Hal ini dikarenakan adanya gaya tarik menarik antar molekul adsorbate dengan karbon aktif di dalam air yang di kenal dengan Van Der Walls. Berdasarkan analisis dengan ChemOffice Profesional 15.0 diperoleh total energy minimalisasi mimimum, perenggangan, dan Stretch-Bend pada suhu 300 Kyang nilainya berturut-turut yaitu $30.3182 \mathrm{kcal} / \mathrm{mol}, 1.4052$ dan -0.1016 . Parameter transfer ion pada senyawa ini dihitung dengan persamaan termodinamika di antaranya kecepatan rata-rata $\mathrm{Hg}\left(\mathrm{NO}_{3}\right)_{2}$ pada suhu $298 \mathrm{~K}$, kecepatan hanyut, konduktivitas termal yaitu 2,289 m/ s,1,769 V/pm, dan 8,3 $\mathrm{W} / \mathrm{m}$.K. Mercury (II) nitrate memiliki sifat termodinamika yaitu $\Delta H=-743,1$ $\mathrm{kj} / \mathrm{mol}, \Delta G=-625,8 \mathrm{kj} / \mathrm{mol}, \Delta S=200,7 \mathrm{~J} / \mathrm{molK}$,
\end{abstract}

Keyword: Raksa (II) Nitrat, adsorpsi, karbon aktif, gaya Van Der Walls, Chem Draw Profesional 15.0 dan Chem 3D

\section{Pendahuluan}

Raksa (II) Nitrat ${ }^{(1-6)}$ adalah senyawa kristalin tidak berwarna putih dengan rumus kimia $\mathrm{Hg}\left(\mathrm{NO}_{3}\right)_{2}$. Senyawa ini pernah digunakan untuk flannel dari bulu hewan ${ }^{(3,7-10)}$. Namun praktik ini dilarang di Amerika Serikat pada Desember 1941. Ungkapan " gila seperti pembuat topi" dalam bahasa inggris mad as a hatter konon terkait dengan penyakit psikologi yang muncul jika terlalu sering terpapar dengan senyawa ini. Namun, pelarangan tersebut bukan atas dasar kesehatan. Tetapi 
karena raksa (II) nitrat sangat dibutuhkan dalam proses pembuatan bahan peledak selama perang dunia $\mathrm{II}^{(37-41)}$.

1) Mercury $(\mathrm{Hg})^{(12,13,16-22,42,43)}$

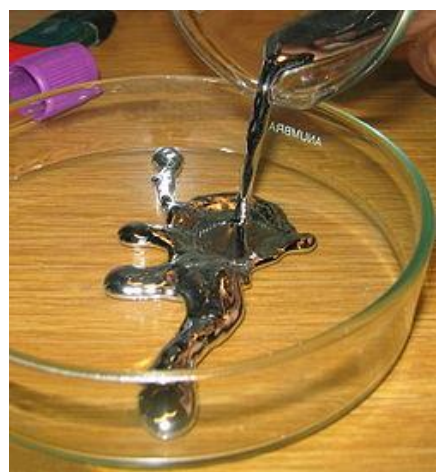

Gambar 1. Wujud raksa pada suhu kamar

Raksa berasal dari bahasa latin yaitu Hydrargyum, terjemahan Bahasa Inggris yaitu mercury yang memiliki arti mudah menguap ${ }^{(44-54)}$. Raksa adalah unsur kimia yang mempunyai nomor atom 80 , berat atom 200,61 dan jari-jari atom 1,48 $\mathrm{A}^{0}$. Raksa merupakan satu-satunya logam yang berwujud cair pada suhu ruang yaitu $25^{\circ} \mathrm{C}$ dan bersifat volatile. Warna dari raksa tergantung pada bentuk fasanya. Raksa dalam wujud cair dapat berupa warna putih perak sedangkan dalam wujud padat berupa warna abu-abu. Densitas raksa lebih tinggi dibandingakan dari semua benda cair yaitu 13,55. Tegangan permukaannya juga tinggi jika dibandingakan dengan alcohol dan air ${ }^{(55-59)}$.

Raksa tidak dapat bereaksi dengan oksigen pada suhu kamar karena memiliki potensial oksidasi sebesar 0,799 volt. Sehingga raksa tidak mudah teroksidasi dan tahan terhadap korosi. Namun pada suhu sekitar titik didih nya sekitar $356,9^{\circ} \mathrm{C}$ raksa dapat bereaksi dengan oksigen membentuk $\mathrm{HgO}$ yang berwarna ${ }^{(60-66)}$

. Senyawa $\mathrm{HgO}$ sangat tidak stabil, sehingga apabila dipanaskan lagi dengan suhu yang lebih tinggi $\mathrm{Hg}$ akan melepaskan oksigennya. Dan apabila raksa mengandung senyawa logam lainnya, misalnya $\mathrm{Zn}$ atau $\mathrm{Pb}$ maka raksa akan lebih sensitive terhadap oksigen. Senyawa logam lain yang bereaksi dengan raksa akan membentuk senyawa yang disebut dengan senyawa amalgam. Raksa bereaksi cepat dengan gas $\mathrm{Cl}_{2}, \mathrm{~S}, \mathrm{Br}_{2}$ dan $\mathrm{N}_{2} \mathrm{O}$ namun tidak dapat bereaksi dengan uap air, katalis atau asam-asam yang tidak oksidator kuat ${ }^{(1,67-72)}$.

Oleh karena itu, pekerjaan yang bayak berhubungan dengan raksa harus dikerjakan dengan sangat hati-hati. Raksa tidak boleh bersentuhan dengan barang-barang yang terbuat dari emas, platina atau perak ${ }^{(71,73-82)}$. Kelarutan raksa sukar larut dengan pelarut pada umumnya namun mudah larut dalam asam nitrat. Di alam raksa dapat membentuk banyak macam senyawa kimia. Senyawasenyawa tersebut dapat dielompokan mejadi 5 kelompok yaitu:

1. Raksa metalik.

2. Garam-garam anorganik, seperti raksa sulfide.

3. Senyawa-senyawa alkil, yaitu raksa yang mengandung senyawa gugus alkil.

4. Senyawa alkoksil-alkil.

5. Senyawa aril, yaitu raksa yang mengandung gugus fenil. ${ }^{(83-92)}$

Senyawa- senyawa ini akan dirubah oleh manusia ke bentuk yang lainnya berupa senyawa baru agar dapat lebih bermanfaat lagi bagi manusia. Thermometer merupakan salah satu contohnya. Raksa merupakan logam yang memiliki kerapatan paling tinggi dalam wujud cair sehingga sangat berat. Raksa dapat membeku pada suhu $-39^{\circ} \mathrm{C}^{(93,94)}$.

Di alam raksa dapat ditemukan dalam bentuk raksa (II) sulfide yang juga disebut dengan mineral cinnabar. Raksa juga banyak ditemukan bebas dalam bentuk logam cair. Kebanyakan 
mineral logam raksa hanya mengandung sedikit sulfit sehingga memiliki harga yang tinggi ${ }^{(55,95-104)}$. Untuk mendapatkan $\mathrm{Hg}$ dari mineral nya dilakukan dengan cara memanaskan $\mathrm{HgS}$ dengan oksigen. Logam Hg akan menguap akibat pemanasan kemudian didinginkan untuk mendapatkan logamnya. Reaksi yang terjadi yaitu :

\section{- Senyawa raksa (II) $\left(\mathrm{Hg}^{2+}\right)$}

$$
\mathrm{HgS}_{(s)}+\mathrm{O}_{2(g)}-\rightarrow H g_{(l)}+\mathrm{SO}_{2(g)}
$$

Secara umum raksa berikatan kovalen. Raksa (II) Nitrat meruapakan salah satu senyawa yang mengadung ion $\mathrm{Hg}^{2+}$ dan senyawa ini dapat larut di dalam air.

- $\quad$ Senyawa raksa (I) $\left(\mathrm{Hg}^{+}\right)$

$\mathrm{HgCl}_{2}$ larut dalam air hangat, tetapi kelarutannya ini tidak menunjukan bahawa senyawa ini merupaka senyawa yang dapat meghantarkan arus litrik. Hal ini disebakan oleh $\mathrm{HgCl}_{2}$ tidak mengion didalam air. Larutan $\mathrm{HgCl}_{2}$ akan cepat tereduksi kedalam senyawa $\mathrm{HgCl}$ yang berwarna putih tetapi tidak larut didalam air.

Raksa (II) oksida merupakan senyawa yang tidak stabil akibat peningkatan suhu dan akan terdekomposisi kembali menjadi logam raksa. HgO yang berbentuk bubuk merah akan berubah menjadi keperakan seperti warna logam. Hal ini sangat menarik untuk didemonstrasikan. Tetapi reaksi dekomposisi HgOsangat berbahaya karena akan membentuk logam raksa lagi dan mudah menguap dan tidak baik untuk kesehatan ${ }^{(2,37,105-114)}$.

Di alam, senyawa $\mathrm{Hg}^{+}$tidak ditemukan secara langsung. Biasanya ion ini ditemukan dalam bentuk raksa (i) klorida dan raksa (I) Nitrat. $\mathrm{Hg}_{2}\left(\mathrm{NO}_{3}\right)_{2}$ merupakan dua senyawa ion $\mathrm{Hg}^{+}$yang pernah diketahui.belum ada yang bias mensintesis senyawa $\mathrm{Hg}^{+}$dengan anion-anion lainnya ${ }^{(27-29)}$

2) Ion nitrat

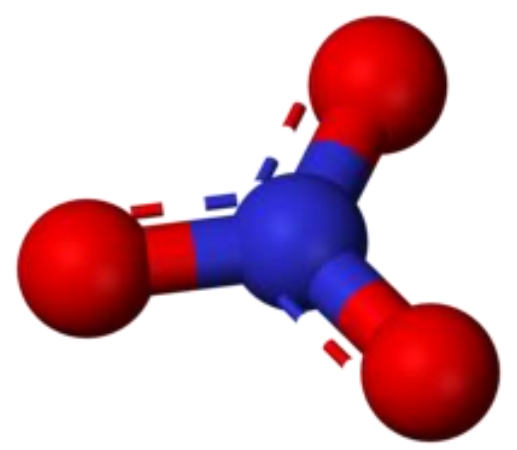

Gambar 2. Ion nitrat dilihat $3 D$

Nitrat merupakan ion poliatomic yang terdiri dari atom $\mathrm{N}$ dan atom $\mathrm{O}$ dengan rumus molekul $\mathrm{NO}_{3}{ }^{2-}$. Nitrat dapat dikelompokan kedalam kimia anorganik. Senyawa ini memiliki bentuk struktur planar geometri trigonal. Hal ini menggambarkan bagaimana susunan atomatom penyusunan dalam ruang tiga dimensi. Ada hanya satu atom oksigen yang terikat ganda dengan atom pusat nitrogen dan oksigen lainnya berikatan melalui ikatan tunggal. Ketika atom oksigen yang identic berikatan satu sama lain diyakini sesuai dengan prinsip resonansi dalam kimia. Oleh karena itu ikatan ganda dapat berimigrasi antara setiap atom oksigen dan atom pusat nitrogen. Nitrogen memiliki bilangan oksidasi +5 . Pada umunya garam nitrat dapat larut dalam air. Jika bercampur dengan air , maka ion-ion nitrat akan membentuk asam nitrat yang dianggap sebagai asam kuat. Senyawa nitrat berguna dalam kehidupan sehari-hari sebagai pupuk untuk pertanian, untuk produksi bahan peledak dan lain-lain ${ }^{(115,116)}$. 


\section{Metoda}

Metode yang digunakan pada preview ini adalah perhitungan secara matematis pada besaran mobilitas ion dan konduktivitas termal, studi literatur menggunakan Endnote X7, dan penggambaran molekul dengan menggunakan aplikasi ChemOffice Proffesional versi 15.0. Tujuan dari penulisan mengetahui dan memahami struktur dan karakterisasi senyawa $\mathrm{Hg}\left(\mathrm{NO}_{3}\right)_{2}$ menggunakan data yang diperoleh dari aplikasi Chem Draw Profesional 15.0 dan Chem 3D. Proses menganalisis data yaitu dengan menghitung MM2 dari molekul $\mathrm{Hg}\left(\mathrm{NO}_{3}\right)_{2}$ yang terdiri dari MM2 minimization, MM2 dynamic, dan MM2 properties. Penulisan ini juga bertujuan untuk mengetahui teknik pemisahan $\mathrm{Hg}$ pada limbah pabrik dengan proses adsorbsi dengan karbon aktif. Data yang diperoleh melalui beberapa jurnal penelitian yang telah dilakukan.

Penelitian dilakukan dengan tahap, yakni (1) Analisis molekul $\mathrm{MgSO}_{4}$ secara dua dimensi dengan menggunakan ChemDraw 2D, (2) Analisis molekul $\mathrm{MgSO}_{4}$ secara tiga dimensi menggunakan Chem3D.

Pada bagian Chem3D, struktur $\mathrm{Hg}\left(\mathrm{NO}_{3}\right)_{2}$ diubah menjadi bentuk 3 dimensi dan kemudian dianalisis, seperti :

1. Menghitung MM2 dari masing-masing molekul yang terdiri atas MM2 minimization, MM2 dynamics dan MM2 properties. Langkahnya dengan klik pada menu calculation, pilih MM2 minimization kemudian klik minimize energy lalu klikrun. Dengan langkah yang sama dilakukan untuk menentukan molecular dynamics dan compute properties.

2. Analisis surface molekul, diantaranya Surface Solvent Accesible dengan tipe solid, wire mesh dan tranculent. Kemudian Surface Connolly Molecular dengan tipe solid, wire mesh dan tranculent.

3. Menghitung nilai MOPAC dari masing-masing molekul yang terdiri dari MOPAC minimization dan MOPAC properties. Caranya dengan pilih MOPAC, kemudian pilih MOPAC minization kemudian pilih run. Dengan cara yang sama untuk menentukan MOPAC properties.

4. Analisis jarak antara masing-masing atom tiap-tiap, molekul dengan pilih bagian structure, kemudian pilih measurement

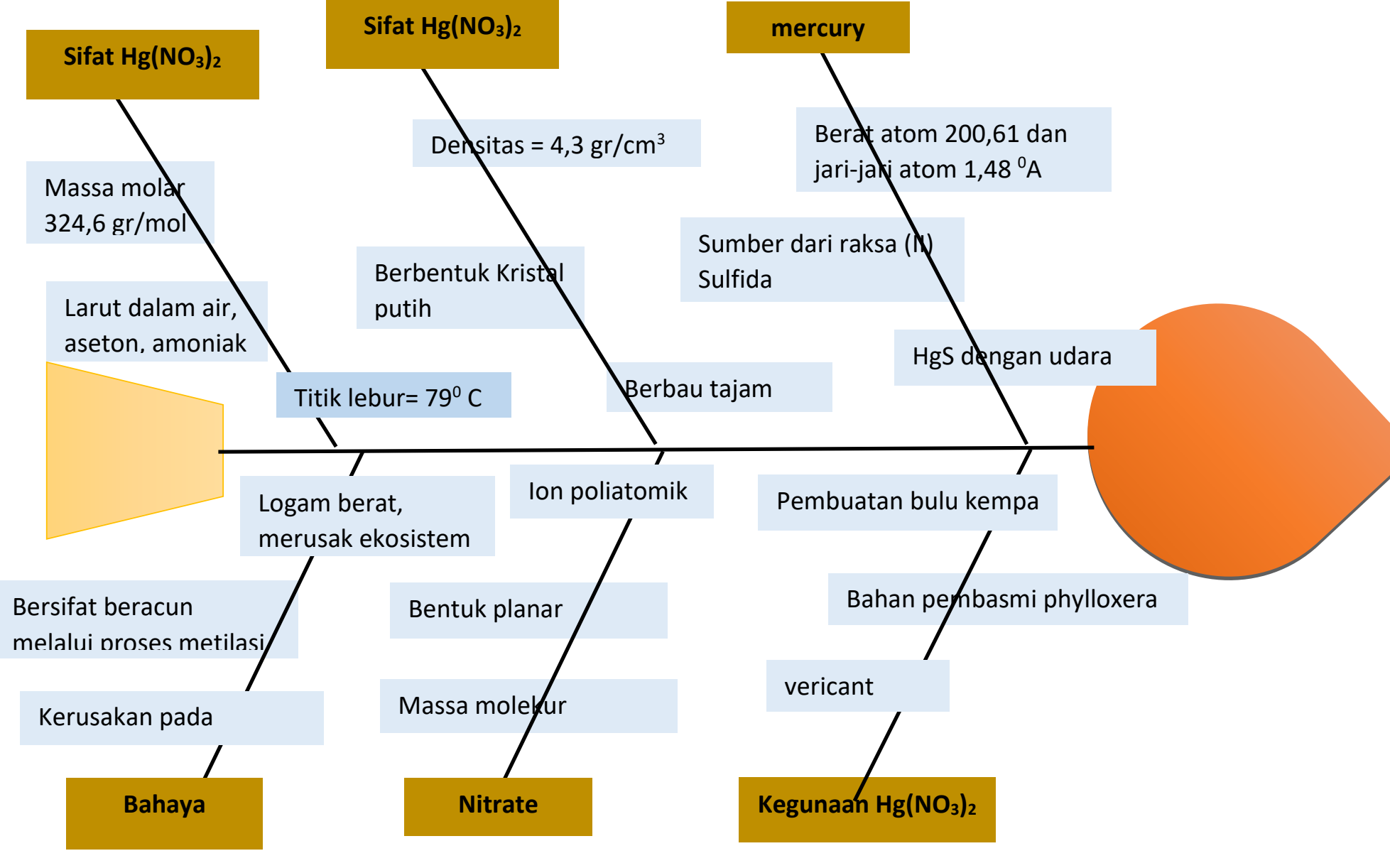




\section{HASIL DAN PEMBAHASAN}

1. Karakteristik $\mathrm{Hg}\left(\mathrm{NO}_{3}\right)_{2}$<smiles>O=[N+]([O-])[O-]</smiles><smiles>O=[N+]([O-])[O-]</smiles>

$$
\mathrm{Hg}^{2+}
$$

mercury (II) nitrate

Gambar 4. Struktur molekul $\mathrm{Hg}\left(\mathrm{NO}_{3}\right)_{2}$ dengan chemdraw $2 \mathrm{D}$

Nama IUPAC

Rumus kimia

Massa molar

Bentuk

Bau

Densitas

Titik lebur

Kelarutan dalam air

Kelarutan
: Raksa (II) nitrat

$: \mathrm{Hg}\left(\mathrm{NO}_{3}\right)_{2}$

: $324,60 \mathrm{gr} / \mathrm{mol}$

: Kristal tak berwarna atau bubuk putih

: Tajam

: $4.3 \mathrm{gr} / \mathrm{cm}^{3}$ ( Monohidrat)

: $79^{\circ} \mathrm{C}\left(174{ }^{\circ} \mathrm{F}, 352 \mathrm{~K}\right)$ mono hidrat

: Dapat larut ${ }^{(30-39)}$

: Dapat larut dalam asam nitrat, aseton, amoniak dan tidak dapat larut dalam alcohol

$$
:-74,0 \cdot 10^{-6} \mathrm{~cm}^{3} / \mathrm{mol}
$$

\section{Analisis 3D pada Molekul $\mathrm{Hg}\left(\mathrm{NO}_{3}\right)_{2}$}

Molekul $\mathrm{Hg}\left(\mathrm{NO}_{3}\right)_{2}$ dapat dibuat menggunakan analisis 3D yang sebelumnyadibuat menggunakan Chemdraw Ultra lalu diproyeksikan menggunakan software Chem3D 15.0. untuk analisis 3 Dimensi. Software ini membantu dalam melihat bagaimana pergerakan molekul dan melihat bagaimana molekul $\mathrm{Hg}\left(\mathrm{NO}_{3}\right)_{2}$ dapat berinteraksi dengan lingkungan ketika splitting berlangsung. Sebelum molekul $\mathrm{Hg}\left(\mathrm{NO}_{3}\right)_{2}$ dioptimasi, atom $\mathrm{Hg}(1)$ dan $\mathrm{O}(5)$ berjarak $2.130 \mathrm{~A}$, atom $\mathrm{O}(4)$ dan $\mathrm{O}(5)$ berjarak $1.428 \mathrm{~A}$ dan sudut ikatan atom $\mathrm{Hg}$ dan $\mathrm{O}-\mathrm{O}$ adalah 109,5 $5^{\circ}$ atom $\mathrm{Hg}(1)$ dan $\mathrm{N}(5)$ berjarak $4.147 \mathrm{~A}$, dan atom $\mathrm{N}(2)$ dan $\mathrm{O}(3)$ berjarak 1.183 A dan sudut ikatan $\mathrm{Hg}$ dan $\mathrm{N}-\mathrm{O}$ adalah $118,0^{\circ}$, 

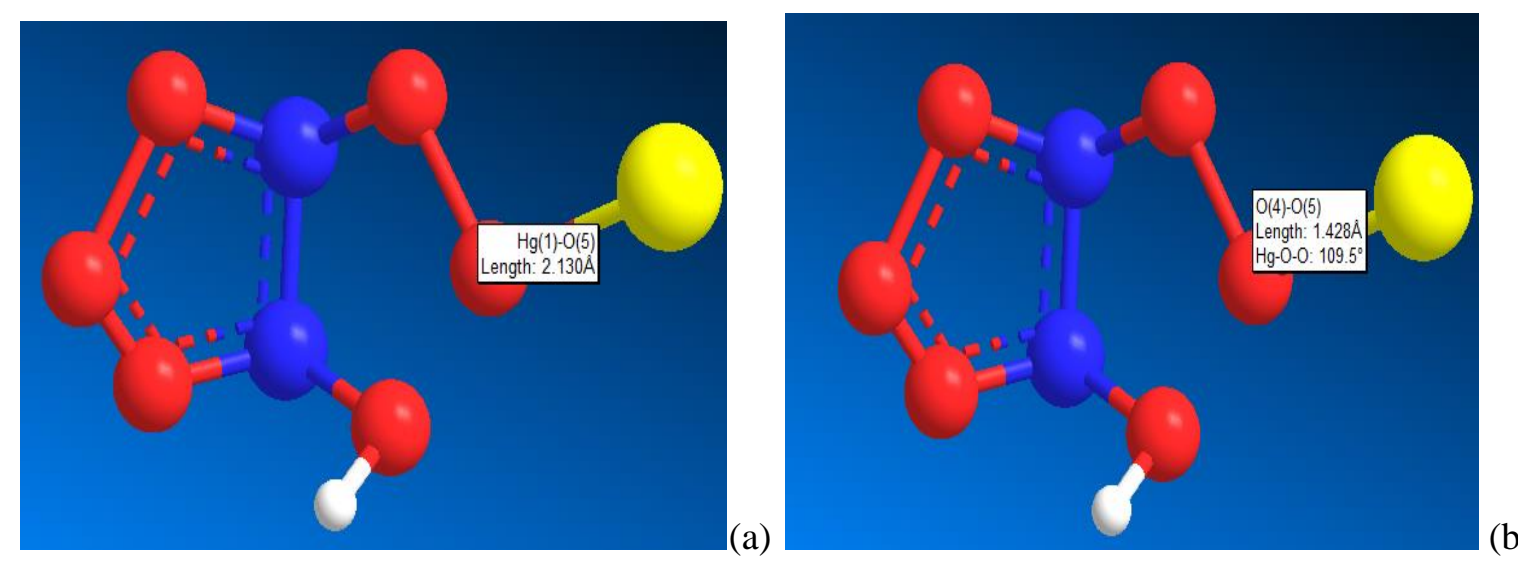

(b)
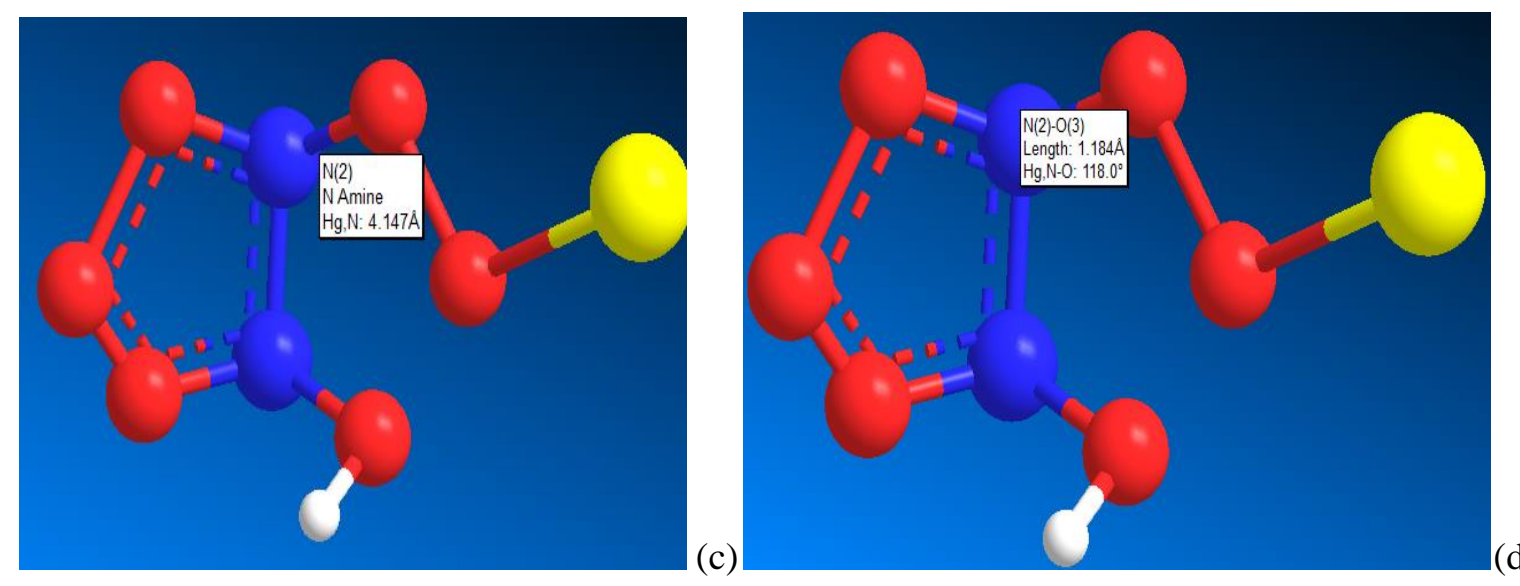

Gambar 1 Analisis 3D pada molekul $\mathrm{Hg}\left(\mathrm{NO}_{3}\right)_{2}$, (a) atom $\mathrm{Hg}(1)$ dan $\mathrm{O}(5)$, (b) Jarak antara atom $\mathrm{O}(4)$ dengan atom $\mathrm{O}(5)$, (c) Jarak antara atom $\mathrm{Hg}(1)$ dengan atom $\mathrm{O}(5)$, (d) Jarak atom $\mathrm{N}(2)$ dengan atom O(3), (Prima, Intan, ChemOffice 15.0)
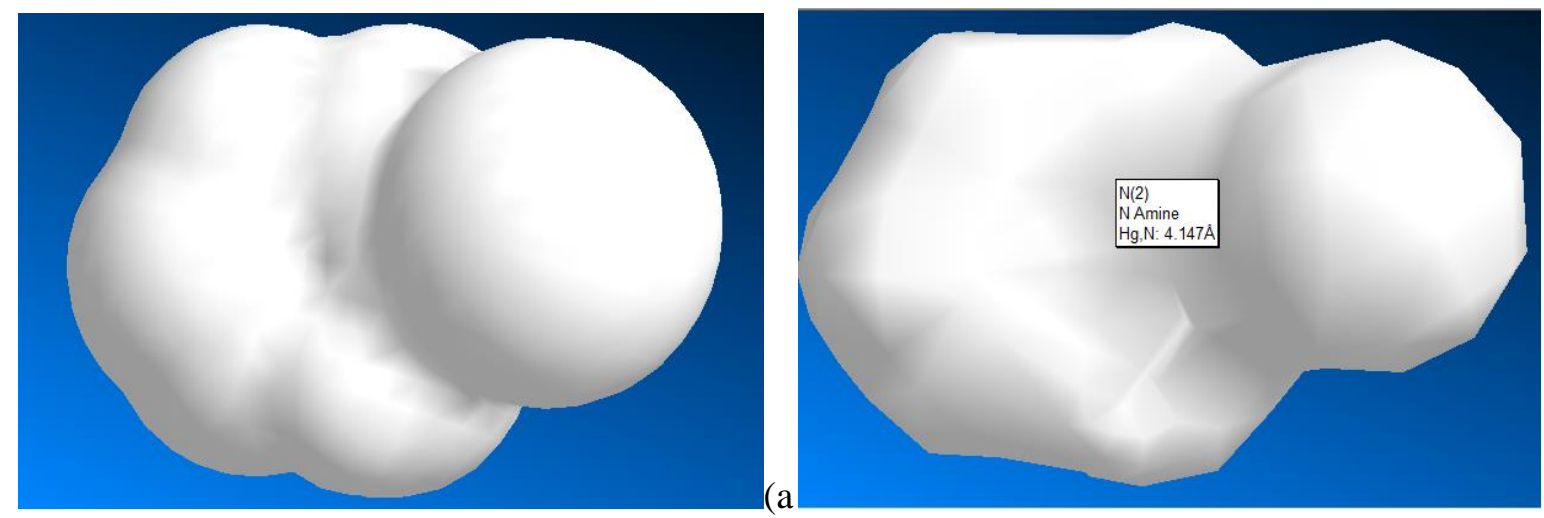

(b) 

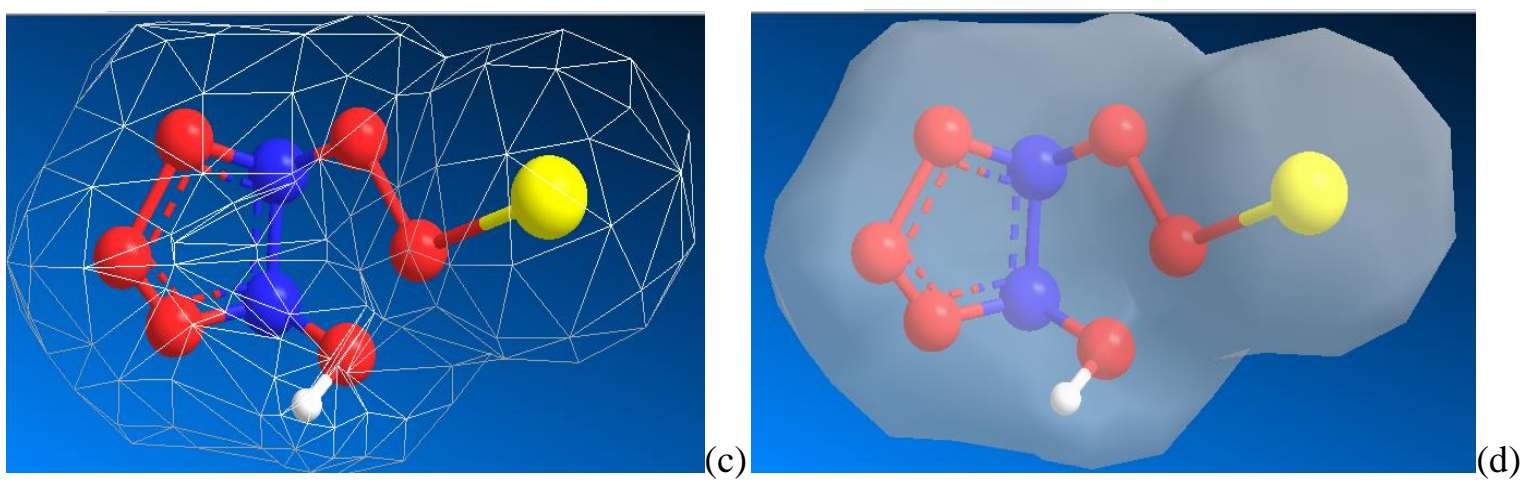

Gambar 2. Analisis 3D pada molekul $\mathrm{Hg}\left(\mathrm{NO}_{3}\right)_{2}$ model Ball and Stick. (a) molekul $\mathrm{Hg}\left(\mathrm{NO}_{3}\right)_{2}$ dengan choose surface model solvent molecular dan display model solid (b) molekul $\mathrm{Hg}\left(\mathrm{NO}_{3}\right)_{2}$ dengan choose surface connoly model accesible dan display model solid (c) molekul $\mathrm{Hg}\left(\mathrm{NO}_{3}\right)_{2}$ dengan choose surface model connoly molecular dan display model wire mash dan (d) molekul $\mathrm{Hg}\left(\mathrm{NO}_{3}\right)_{2}$ dengan choose surface model connoly molecular dan display model translucen (Prima, Intan. ChemOffice 15.0).

\subsection{Optimasi MM2}

MM2 Calculation completed successfully -MM2 Dynamics-

Warning: Some parameters are guessed (Quality $=1)$.

Iteration Time Total Energy Potential Energy Temperature

$$
\begin{array}{cccccc}
1 & 0.002 & 288.792 \pm 0.000 & 210.233 \pm 0.000 & 1098.14 \pm 0.00 \\
2 & 0.004 & 291.826 \pm 0.000 & 124.917 \pm 0.000 & 2333.14 \pm 0.00 \\
3 & 0.006 & 291.910 \pm 0.000 & 130.757 \pm 0.000 & 2252.68 \pm 0.00 \\
4 & 0.008 & 289.990 \pm 0.000 & 161.441 \pm 0.000 & 1796.92 \pm 0.00 \\
5 & 0.010 & 289.608 \pm 0.000 & 166.447 \pm 0.000 & 1721.61 \pm 0.00
\end{array}
$$

\subsection{MM2 minimized}

MM2 Minimization

Warning: Some parameters are guessed (Quality $=1$ ).

Iteration 1 Steric Energy 1632.115 RMS Gradient 719.245 RMS Move 0.0000

Iteration 2 Steric Energy 695.021 RMS Gradient 197.894 RMS Move 0.0315

Iteration 3 Steric Energy 538.751 RMS Gradient 235.739 RMS Move 0.0589

Iteration 4 Steric Energy 294.211 RMS Gradient 103.630 RMS Move 0.0356

Iteration 5 Steric Energy 239.657 RMS Gradient 68.895 RMS Move 0.0340

Iteration 6 Steric Energy 176.597 RMS Gradient 79.978 RMS Move 0.0437

Iteration 7 Steric Energy 115.307 RMS Gradient 71.805 RMS Move 0.0428

Iteration 8 Steric Energy 84.902 RMS Gradient 53.211 RMS Move 0.0205

Iteration 9 Steric Energy 65.105 RMS Gradient 22.699 RMS Move 0.0083

Iteration 10 Steric Energy 59.648 RMS Gradient 17.828 RMS Move 0.0074

Iteration 329: Minimization terminated normally because the gradient norm is less than the minimum gradient norm

Stretch: $\quad 1.4052$

Bend: $\quad 2.8891$

Stretch-Bend: $\quad-0.1016$

Torsion: $\quad 0.0000$ 


$\begin{array}{ll}\text { Non-1,4 VDW: } & -1.8588 \\ \text { 1,4 VDW: } & 6.7410 \\ \text { Dipole/Dipole: } & 21.2432 \\ \text { Total Energy: } & 30.3182 \mathrm{kcal} / \mathrm{mol} \\ \text { MM2 Properties } & \\ \text { MM2 Calculation } & \\ \text { MM2 Propleted successfully } \\ \text { Warning: Some parameters are guessed (Quality = 1). } \\ \text { Stretch: } & 1.4052 \\ \text { Bend: } & 2.8891 \\ \text { Stretch-Bend: } & -0.1016 \\ \text { Torsion: } & 0.0000 \\ \text { Non-1,4 VDW: } & -1.8588 \\ \text { 1,4 VDW: } & 6.7410 \\ \text { Dipole/Dipole: } & 21.2432 \\ \text { Total Energy: } & 30.3182 \mathrm{kcal} / \mathrm{mol}\end{array}$

\section{Mercury}

\begin{tabular}{|c|c|c|}
\hline Nomor atom & & $: 80$ \\
\hline Berat atom & : 200,61 & \\
\hline Jari-jari atom & & $: 1,48^{\circ} \mathrm{A}$ \\
\hline Sifat & & : volatile \\
\hline Wujud & & : cair (suhu ruangan) \\
\hline Densitas & $: 13,55$ & \\
\hline Konduktivitas ok & dasi & : 0,799 volt \\
\hline Titik didih & $: 356,9^{\circ}$ & \\
\hline Tegangan permuk & & : 547 dyne \\
\hline
\end{tabular}

Senyawa $\mathrm{HgO}$ sangat tidak stabil, sehingga apabila dipanaskan lagi dengan suhu yang lebih tinggi $\mathrm{Hg}$ akan melepaskan oksigennya. Jika raksa mengandung senyawa logam lainnya, misalnya $\mathrm{Zn}$ atau $\mathrm{Pb}$ maka raksa akan lebih sensitive terhadap oksigen. Senyawa logam lain yang bereaksi dengan raksa akan membentuk senyawa yang disebut dengan senyawa amalgam. Raksa bereaksi cepat dengan gas $\mathrm{Cl}_{2}, \mathrm{~S}, \mathrm{Br}_{2}$ dan $\mathrm{N}_{2} \mathrm{O}$ namun tidak dapat bereaksi dengan uap air, katalis atau aam-asam yang tidak oksidator kuat.

Di alam, senyawa $\mathrm{Hg}^{+}$tidak ditemukan secara langsung. Biasanya ion ini ditemukan dalam bentuk raksa (i) klorida dan raksa (I) Nitrat. $\mathrm{Hg}_{2}\left(\mathrm{NO}_{3}\right)_{2}$ merupakan dua senyawa ion $\mathrm{Hg}^{+}$yang pernah diketahui.belum ada yang bias mensintesis senyawa $\mathrm{Hg}^{+}$dengan anion-anion lainnya.

\section{Nitrate}

Nitrat merupakan ion poli atomic yang terdiri dari atom $\mathrm{N}$ dan atom $\mathrm{O}$ dengan rumus molekul $\mathrm{NO}_{3}{ }^{2-}$. nitrat dapat dikelompokan kedalam kimia anorganik. Senyawa ini memiliki bentuk struktur planar geometri trigonal. Hal ini menggambarkan bagaimana susunan atom-atom penyusunan dalam ruang tiga dimensi. Ada hanya satu atom oksigen yang terikat ganda dengan atom pusat nitrogen dan oksigen lainnya berikatan melalui ikatan tunggal. Ketika atom oksigen yang identic berikatan satu sama lain diyakini sesuai dengan prinsip resonansi dalam kimia. Oleh karena itu ikatan ganda dapat berimigrasi antara setiap atom oksigen dan atom pusat nitrogen. Nitrogen memiliki bilangan oksidasi +5 . Pada umunya garam nitrat dapat larut dalam air. 


\section{Sintesis $\mathrm{Hg}\left(\mathrm{NO}_{3}\right)_{2}$}

Mercury(II) Nitrate tidak ditemukan dialam bebas seperti garam pada umumnya. Senyawa ini dibuat dengan mereaksikan logam raksa dan asam nitrat dengan suhu yang tinggi. Asam nitrat dalam reaksi ini akan berperan sebagai oksidator.

Persamaan reaksi:

$$
6 \mathrm{Hg}+6 \mathrm{HNO}_{3}---\rightarrow 3 \mathrm{Hg}_{2}^{2+}+2 \mathrm{NO}+6 \mathrm{NO}_{3}^{-}+4 \mathrm{H}_{2} \mathrm{O}
$$

\section{Kegunaan $\mathrm{Hg}\left(\mathrm{NO}_{3}\right)_{2}$}

1) Pembuatan bulu kempa

2) Bahan pembuatan almogam gigi

3) Thermometer

4) Barometer

5) Peralatan ilmiah

\section{Parameter sifat termokimia}

\subsection{Transfer ion}

Sifat transport adalah kemampuan zat itu untuk memindahkan materi, energi atau suatu sifat tertentu lainnya dari satu tempat ke tempat lain ${ }^{(3-11)}$.. Contohnya, molekul molekul (dalam gas, cairan, dan padatan) berdifusi menuruti suatu gradien konsentrasi, sampai komposisinya seragam. Laju difusi ini merupakan sifat transpor. Laju konduksi termal, transpor energi menuruti gradien temperatur, merupakan sifat transpor lainnya yang merupakan sifat umum zat dan keadaannya. Konduksi listrik merupakan transpor muatan (oleh ion atau elektron) dalam gradien potensial, dan konduktivitas listrik zat juga merupakan sifat transpor. Viskositas, seperti akan kita lihat, adalah ukuran laju ditransportasikannya momentum linear melalui fluida, dan karenanya inipun merupakan sifat transpor ${ }^{(12-22)}$.

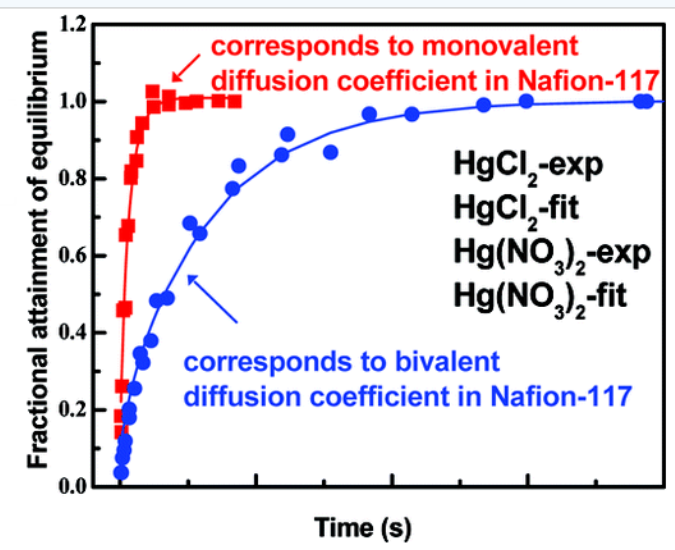

Berdasarkan hasil penelitian pertukaran isotope kinetic $\mathrm{Hg}$, ion mercury difusi kedalam membrane kation monovalent dari $\mathrm{HgCl} 2$ sementara $\mathrm{Hg}\left(\mathrm{NO}_{3}\right)_{2}$ terdifusi kedalam mebran kation divalent. Persamaan The Nerst Plank tidak dapat memprediksi kinetika $\mathrm{NaCl}$ sebagai garam eksternal. Hal ini menunjukan bahawa komplesasi dalam membrane mempengaruhi kinetic. 
Grafik diatas menunjukan perbedaan luas spesies yang ada dalam larutan dan perbedaan transfor ion larutan ${ }^{(186-188,203)}$.

\subsection{Konduktivitas}

Andaikan setiap molekul membawa energi rata-rata $\varepsilon=v \mathrm{kT}$, dengan $v$ merupakan bilangan mendekati 1 yang dapat diperoleh dari teori ekuipartisi ${ }^{(204-210)}$. untuk partikel beratom tunggal, $v=\frac{3}{2}$. Jika suatu molekul melewati jendela bayangan, molekul ini mentranfortasikan energi rata-rata itu. Kita akan mengandaikan bahwa rapatan jumlah seragam (sehingga tidak ada difusi massa), tetapi tempetatur tidak. Secara rata-rata, molekul datang dari sebelah kiri setelah menjalani jalan bebas rata-rata dari daerah yang lebih panas, dan dengan energi yang lebih tinggi. Molekul juga datang dari sebelah kanan setelah menjalani jalan bebas rata-rata dari daerah yang lebih dingin. Oleh karena itu fluks energy ${ }^{(256)}$ dalam dua arah adalah :

$$
\begin{array}{lr}
\mathrm{J}(\mathrm{L} \rightarrow \mathrm{R})=\frac{1}{4^{\mathrm{c}}} N \varepsilon(-\lambda) & \varepsilon(-\lambda)=v k\left\{\mathrm{~T}-\lambda\left(\begin{array}{l}
d T \\
d z
\end{array}\right)\right. \\
\mathrm{J}(\mathrm{L} \leftarrow \mathrm{R})=\frac{1}{4^{\mathrm{c}}} N \varepsilon(-\lambda) & \varepsilon(\lambda)=v k\left\{\mathrm{~T}-\lambda\left(\begin{array}{l}
d T \\
d z
\end{array}\right) .\right.
\end{array}
$$

Makaa fluks energi neto :

$\mathrm{J}_{\mathrm{z}=\mathrm{J}} \mathrm{J}(\mathrm{L} \rightarrow \mathrm{R})-\left(\mathrm{J}(\mathrm{L} \leftarrow \mathrm{R})=\frac{1}{2} v \lambda \bar{c} k N\left(\begin{array}{l}d T \\ d z\end{array}\right) o\right.$

Seperti sebelumnya, kita mengalikannya dengan $\frac{3}{2}$ untuk memperhatikan jalan aliran yang panjang, sehingga kita sampai pada :

$$
\mathrm{J}_{\mathrm{Z}}=\frac{1}{3} v \lambda \bar{c} k N\left(\begin{array}{l}
d T \\
d z
\end{array}\right)
$$

Fluks energi sebanding dengan gradien temperatur, seperti yang ingin kita buktikan. Perbandingan persamaan ini dengan persamaan 16, membuktikan bahwa:

$$
\mathrm{K}=\frac{1}{3} v \lambda \bar{c} K n
$$

Karena untuk gas sempurna $\mathrm{C}_{v}=v k \mathrm{~N}_{\mathrm{A}}$, maka kita dapat menyatakan persamaan ini sebagai:

$$
\mathrm{K}=\frac{1}{3} \lambda \bar{c} C_{v}[\mathrm{~A}]
$$


Dengan [A] merupakan konsentrasi molar ${ }^{2}$.

Dalam kedua kasus itu, ketahuilah bahwa karena $\lambda \infty 0$ 1/[A] (persamaan 12c), maka $K \infty$ $\overline{\mathrm{c}}_{v}$ dan konduktivitas termal ${ }^{(180-185)}$ tidak bergantung pada tekanan gas. Alasan fisiknya adalah: konduktivitas termal besar jika banyak molekul yang tersedia untuk mentransformasikan energi itu (karenanya $K$ sebanding dengan [A] dalam persamaan 20); tetapi banyaknya molekul membatasi jalan bebas rata-rata, sehingga molekul itu tidak dapat membawa energi pada jarak yang jauh. Kedua efek ini berimbang. Dari eksperimen ternyata bahwa konduktivitas termal tidak bergantung pada temperatur, kecuali jika tekanan sangat rendah. Pada tekanan rendah $K \infty \mathrm{p}$ karena $\lambda$, lebih besar dari dimensi alat, dan jarak transfortasikannya energi ditentukan oleh ukuran labu, bukan oleh adanya molekul lain. Fluks masih sebanding dengan jumlah pembawa, tetapi panjang jalannya tidak lagi bergantung pada $\lambda$ sehingga ${ }_{K} \infty[\mathrm{A}] \infty \mathrm{p}$.

Konduktivitas atau hantaran termal menggambarkan daya atau kemampuan suatu bahan untuk dapat menghantarkan listrik. Kemampuan ini dimana adanya perbedaan temperature sehingga adanya transfer dari daerah yang panas ke temperature yang lebih rendah.

\subsection{Kecepatan hanyut}

Partikel bermuatan bergerak dalam suatu konduktor akan terus bergerak secara acak seperti patikel gas. Jika dua elektroda dipisah dengan jarak 1 dan berada pada selisih potensial $\Delta \phi$, maka ion dalam larutan di antara kedua elektroda itu, mengalami medan listrik seragam,yaitu:

$$
E=\frac{\Delta \phi}{\imath}
$$

Dalam medan demikian,ion yang bwermuatan ${ }^{2} z e$ mengalami gaya sebesar :

$$
\begin{array}{ll} 
& \text { Ie }=z e E=\frac{z e \Delta \phi}{\iota} \\
& f=6 \pi \eta a \\
& =6 \times 3,14 \times 1 \times 300 \mathrm{pm} \\
& =5,652 \mathrm{pm} \\
S & =\frac{z e . E}{f} \\
= & \frac{1.10 \mathrm{~V}}{5,652 \mathrm{pm}} \\
= & 1,769 \mathrm{~V} / \mathrm{pm}
\end{array}
$$

Kecepatan velositas ${ }^{(172-179)}$ dari eloktron didalam mercury menguap pada suhu $573 \mathrm{~K}$ yang telah diukur menggunakan metoda Bradbury Nielen pada angka densitas mulai dari 3,40 X $10^{17}$ to $1,83 \times 10^{18} \mathrm{~cm}^{-3}$. Kecepatan velocity naik denagn linear dengan densitas mercury ${ }^{(12-22)}$.

\subsection{Viskositas}

Kita sudah melihat bahwa viskositas berhubungan dengan fluks momentum. Molekul yang berjalan dari kanan dalam (dari lapisan cepat kelapisan lebih lambat) mentransportasikan momentum $m v_{x}(\lambda)$ kelapisan yang barupada $\mathrm{z}=0$, dan molekul yang berjalan dari kiri mentransportasikan $m v_{x}(-\lambda)$ kelapisan baru itu. Jika kita mengasumsikan bahwa rapataannya seragam ( suatu pendekatan ), maka jumlah benturan per satuan luar per satuan waktu pada jendela bayangan adalah $\frac{1}{4} \mathcal{N} c$. Molekulnya dari kanan, secara rata-rata membawa momentum : 


$$
\begin{aligned}
& m v_{x}(\lambda)=m v_{x}(0)+ \\
& m \lambda\left(\frac{d v_{x}}{d z}\right)
\end{aligned}
$$

Molekul dari kiri, membawa momentum :

$$
m v_{x}(-\lambda)=m v_{x}(0)-m \lambda\left(\frac{d v_{x}}{d z}\right)_{0} \ldots
$$

Jadi, fluks neto momentum $-\mathrm{x}$ dalam arah $\mathrm{z}$ adalah :

$$
\begin{aligned}
& J_{z}=\frac{1}{4} \mathcal{N} c\left\{\left[m v_{x}(0)-m \lambda\left(\frac{d v_{x}}{d z}\right)_{0}\right]-\left[m v_{x}(0)+m \lambda\left(\frac{d v_{x}}{d z}\right)_{0}\right]\right\} \\
& =-\frac{1}{2} \mathcal{N} m \lambda \bar{c}\left(\frac{d v_{x}}{d z}\right)_{0}
\end{aligned}
$$

Kita melihat bahwa fluks itu sebanding dengan gradient velositas, seperti yang ingin kita buktikan. Jika kita membandingkan ungkapan itu engan persamaan 17, dan mengalikannya secara biasa dengan $\frac{2}{3}$, maka kitadapat menunjukkan viskositas dengan

$$
\eta=\frac{1}{3} \mathcal{N} m \lambda \bar{c}=\frac{1}{3} \mathcal{N} m \lambda \bar{c} \mathcal{N}_{a}[A]
$$

Seperti juga konduktivitas termal, viskositas tidak tergantung pada tekanan. Jadi $\lambda \propto 1 / p$ dan $[A] \propto p$, menunjukkan bahwa $\eta \propto \bar{c}$ tidak yang mentransportasikan momentum, tetapi pengangkutan itu tidak begitu jauh karena lebih pendeknya jalan bebas rata-rata. Karena $\bar{c} \propto T^{1 / 2}$, maka viskositas sebanding dengan $T^{1 / 2}$. Jadi, viskositas gas bertambah dengan naiknya temperatur: molekul berjalan lebih cepat, dan fluks momentum lebih besar.

\subsection{Pengukuran viskositas gas}

Tempat dua teknik utama untuk mengatur viskositas gas $^{(2)}$. Teknik pertama bergantung pada laju perendaman osilasi puntir dari piringan yang tergantung dalam gas, yaitu konstanta waktu untuk pengurangan gerakan harmonis, yang bergantung pada viskositas dan rancangan peralatannya. Teknik kedua didasarkan pada rumus Poiseuilleuntuk laju aliran fluida melalui pipa dengan radius $r$.

$$
\frac{d V}{d t}=\frac{\left(p_{1}^{2}-p_{2}^{2}\right) \pi r^{4}}{16 \ln p_{0}}
$$


dengan $\mathrm{V}$ merupakan volume aliran, $p_{l}$ dan $p_{2}$ tekanan pada setiap ujung pipa sepanjang $l$, dan $p_{0}$ adalah tekanan pada saat pengukuran volume.

Pengukuran ini menegaskan bahwa viskositas gas $^{(211-223)}$ tidak bergantung pada tekanan, pada jarak yang lebar. Misalnya, pengukuran pada argon dari $10^{-3}$ atm sampai $10^{2}$ atm terlihat dalam Gambar 24.11, dan kita melihat bahwa $\eta$ konstan dari sekitar 0,01 atm sampai 50 atm. Pengukuran ini juga menegaskan (sampai taraf lebih kurang) akan ketergantungan viskositas pada $T^{1 / 2}$. Garis putus-putus pada gambar memperlihatkan nilai hasil hitungan menggunakan $\sigma=22 \times$ $10^{-20} \mathrm{~m}^{2}$, yang menunjukkan diameter tumbukan sebesar $260 \mathrm{pm}$. Bandingkanlah nilai ini dengan diameter van der Waals sebesar $335 \mathrm{pm}$, yang diperoleh dari rapatan padatan. Persesuaian ini tidak terlalu buruk, mengingat kesederhanaan model itu dan pengabaian gaya antar molekul ${ }^{(245-250)}$.

\subsection{Akar rata rata kuadrat kecepatan molekul}

Setiap partikel pada gas memeiliki energy kinetic dan untuk gas ideal energy kineti. Karena molekul'molekul gas tidak seluruhnya bergerak dalam kecepatan ${ }^{(28,29,188,189)}$ yang sama, maka perlu mendivisikan.

Rapatan jumlah $\mathrm{N}$ sama dengan $N / V$, dengan $\mathrm{N}$ merupakan jumlah total partikel yang ada dalam volume $\mathrm{V}$. Karena $\mathrm{N}=\mathrm{nN}_{\mathrm{A}}$, dengan $\mathrm{N}_{\mathrm{A}}$ merupakan konstata Avogadro, maka :

$$
\mathrm{P}=\frac{1}{3} \mathrm{n} \text { NA m c2 }
$$

Gas sempurna memenuhi persamaan keadaan, maka :

$$
p V=n R T=n N_{A} k T
$$

dengan $k$ merupakan konstanta Boltzman. Jadi , kita dapat menyimpulkan bahwa :

$\mathrm{c}=\left(\frac{3 k T}{m}\right)^{1 / 2}$

kecepatan rata-rata molekul $\mathrm{Hg}\left(\mathrm{NO}_{3}\right)_{2}$ pada $298 \mathrm{~K}$

$$
C=\left(\frac{3 k T}{m}\right)^{\frac{1}{2}}
$$

$=\left(\frac{3 \times 8,314 \mathrm{~kg} \mathrm{~m} / \mathrm{sK}^{-1} \mathrm{~mol}^{-1} \times 298 \mathrm{~K}}{324,6 \times 10 \mathrm{Kg} \mathrm{mol}^{-1}}\right)^{1 / 2}$

$=2,289 \mathrm{~m} / \mathrm{s}$

Akar rata-rata kuadrat kecepatan bertambah dengan penambahan kuadrat akar temperatur, dan berbanding terbalik dengan kuadrat akar massa molar. Jadi mendua-kalikan temperatur ( misalnya $300 \mathrm{~K}$ menjadi $600 \mathrm{~K}$ ) akan menaikan c dengan faktor 1,4.

6.7 Distribusi velositas ${ }^{(190-195)}$ 
Untuk memperoleh kemajuan, kita perlu mendekati beberapa sifat nilai rata-rata dan perhitungannya. Sifat yang kita perlukan, ditinjau kembali dalam subbab informasi lanjutan pada bagian akhir bab ini. Secara singkat nilai rata-rata $X$ mempunyai nilai berapapun dari suatu jarak nilai kontinu ( seperti kecepatan) adalah: Fungsi $f(\mathrm{~V})$ yang disebut distribusi sifat $\mathrm{X}$, menyataka peluang terletaknya sifat itu dalam jarak $X$ sampai $X+d X^{(196-198)}$.

Ungkapan di bawah ini kita turunkan untuk distribusi kecepatan molekul dengan massa molar M pada temperature $\mathrm{T}$ :

$f(v)=4 \pi\left(\frac{M}{2 \pi R T}\right)^{\frac{3}{2}} v^{2} e^{-M v^{2} / 2 R T}$

dari kecepatan rata-rata diatas dapat dihitung peluang ditemukannya molekul $\mathrm{Hg}\left(\mathrm{NO}_{3}\right)_{2}$ pada 298 $\mathrm{K}$.

$f(v)=4 \pi\left(\frac{M}{2 \pi R T}\right)^{\frac{3}{2}} v^{2} e^{-M v^{2} / 2 R T}$

$f(v)=4.3,14\left(\frac{324,610^{-3} 10 \mathrm{~kg} / \mathrm{mol}}{2.3,14.0,082 \mathrm{~L} \mathrm{~atm} / \mathrm{molK} 298 \mathrm{~K}}\right)^{\frac{3}{2}}(2,289 \mathrm{~m} / \mathrm{s})^{2} \mathrm{e}^{-\frac{3246.5,239}{20,082} .298 \mathrm{~K}}$

$f(v)=28,6 \cdot 10^{-2} \mathrm{~m} / \mathrm{s}$

oleh karena itu,

$p=f(v) x \Delta v$

$=\frac{14,3 \cdot 10^{-2} \mathrm{~m}}{\mathrm{~s}} \times 2,0 \mathrm{~m} / \mathrm{s}$

Jadi, 1 dalam 222 molekul mungkin ditemukan dalam jarak itu.

Sifat kedua dari nilai rata-rata yang kan kita gunakan , bersangkjtan dengan peluang bahwa dua sifat mempunyai nilai khusu suara bersamaan. Jika peluang terletaknya sebuah sifat dalam jarak $Y$ sampai $X+d X$ adalah $f(X) d X$, dan peluang terletaknya sifat bebas $Y$ dalam jarak $Y$ sampai $Y+d Y$, maka peluang terletaknya $X$ dan $Y$ secara bersamaan dalam jarak ini, merupakan hasil kali peluang individualnya.

Distribusi Max Well Boltzman menggambarkan kecepatan partikel dalam gas, dimana partikel bergerak bebas antara tumbukan kecil, tetapi tidak berinteraksi satu sama lain. Sebagai fungsi suhu dari system, massa partikel, dan kecepatan partikel ${ }^{(199,200)}$. Partikel dalam konteks ini mengacu pada atom dan molekul gas. Tidak ada perbedaan antara keduanya dalam perkembangan dan hasilnya.

\subsection{Mobilitas ion}

Mobilitas ion menggambarkan hubungan kuantitas teoris dan kuantitas yang dapat diukur. Kita harus mengetahui sebelumnya bagaimana perbedaan pergerakan ion dan laju dapat terjadi pada ion yang berbeda. Hal ini disebakan konduktivitas molar elektrolit kuat berkurang dengan akar konsentrasi. Dengan meningkatnya mobilitas ion di dalam larutan maka kontribusi ion pada konduktivitas semakin meningkat pula. 
Mobilitas ion $\mathrm{NO}_{3}{ }^{-}$dalam larutan berair pada $25^{\circ} \mathrm{C}$ adalah $7.4 \times 10^{-3} \mathrm{~m} \mathrm{~s}^{-1} \mathrm{v}^{-1}$. Konstanta difusi ion itu dalam air pada $25^{\circ} \mathrm{C}$, dapat dihitung dengan cara

$$
\begin{array}{ll}
\mathrm{D}=\frac{K . T}{6 \pi r} & \\
7,4 \times 10^{-8} m^{2} s^{-1} v^{-1} & =\frac{K .298^{\circ} \mathrm{K}}{6 \times 3,14 \times 4.59} \\
7,4 \times 10^{-8} m^{2} s^{-1} v^{-1} & =\frac{K X 298^{\circ} K}{6 \times 3,14 \times 4.59} \\
639,91 \times 10^{-8} m^{2} s^{-1} v^{-1} & =\mathrm{K} \times 298^{\circ} \mathrm{K} \\
\mathrm{K}=2,14710^{-16} \mathrm{~J} / \text { atom } \mathrm{K}
\end{array}
$$

Jadi, konstanta difusi ion adalah $\mathrm{K}=2,14710^{-16} \mathrm{~J} /$ atom $\mathrm{K}$

\section{Adsorpsi Hg dengan karbon Aktif}

Pada zaman ini, banyak nya industry-industri yang dibagun di dekat perairan. Tidak banyak juga yang menyebabkan pencemaran terhadap lingkungan. Hal ini disebabkan oleh kurangnya pengolahan limbah pabrik dan tindakan lanjut terhadap limbah oleh pihak pabrik itu sendiri. Industry pertanian, tambang emas, alat-alat listri dan pabrik yang menghasilkan logam berat lainnya yang berada disekitar perairan mengakibatkan kadar pencemaran di perairan semakin meningkat ${ }^{(117-122)}$. Apabila kadar logam berat yang dihasilkan oleh limbah telah melebihi batasnya, maka akan menyebabkan menurunnya kualitas perairan dan menganggu kehidupan organisme di dalamnya. Salah satu logam tersebut yaitu raksa atau yang lebih dikenal dengan mercury. Logam merkuri hasil limbah akan di ubah oleh mikroorganisme menjadi metil merkuri yang memiliki sifat beracun bagi organisme di dalamnya ${ }^{(123-127)}$.

Mercury merupakan unsur yang dijaga ketat yang dibatasi kadar nya kurang dari $1 \mu \mathrm{g} / \mathrm{l}$ (mikrogram per liter). Senyawa ini banyak ditemui di sekitar peraian yang dekat dengan kegiatan industry pabrik, pembuangan terakhir sampah, air scrubber dan lain-lainnya ${ }^{(128-132)}$.

Air raksa atau hydrargyum termasuk salah satu logam berat yang mudah menguap pada temperature kamar. Saat ini, mercuri banyak digunakan sebagai campuran alat kosmetik, fungisida, bakterisida dan lainnya ${ }^{(133-137)}$. Air raksa merupakan racun sistematik yang dapat terakumulasi didalam organ tubuh makhluk hidup seperti ginjal, hati, limpa atau tulang. Logam ini akan dikeluarkan dari tubuh dalam proses eksresi melewati urine, feses, keringat, saliva, dan air susu. Jika tubuh mendapati keracunan logam berat ini akan menimbulkan gejala susunan saraf pusat seperti kelainan kepribadian, pikun, insomnia, kehilangan keprcayaan diri, iritasi, depresi. $\mathrm{Hg}$ secara organic dapat merusak susunan saraf pusat(tremor, ataxia, lapangan penglihatan menciut, perubahan kepribadian), sedangkan $\mathrm{Hg}$ anorganik bisanya merusak ginjal, dan menyebabkan cacat bawaaan. Di alam, $\mathrm{Hg}$ anorganik dapat berubah menjadi organik dan sebaliknya karena adanya interaksi dengan mikroba. Genus Pseudomonas dan Neurospora dapat mengubah $\mathrm{Hg}$ anorganik menjadi organik. Staphilococcus aureus antara lain dapat mereduksi $\mathrm{Hg} 2+$ menjadi $\mathrm{Hg}$ elemental. Oleh karena itu konsentrasi logam merkuri atau air raksa di dalam air limbah atau khususnya di dalam air minum harus dikontrol dengan sangat ketat ${ }^{(138-147) \text {. }}$

Upaya yang dapat dilakukan untuk menangani $\mathrm{Hg}$ yang mengandung senyawa organic adalah dengan degrasi pengotor tersebut menggunkan reaksi feton. Reaksi feton sangat efektif untuk menghilangkan pengotor organi. Cara ini sudah diterapkan untuk pengolahan berbagai macam limbah industry yang mengandung senyawa organic beracun seperti formaldehida, BTEX (benzena, toluena, etilbenzena, dan xilena), dan limbah kompleks dari pestisida, cat, maupun zat 
aditif plastik. Metoda ini memiliki kelebihan diantaranya lebih ekonomis, efektif, produksinya lebih aman dan tidak atsiri. Penelitian sebelumnya telah menunjukan bahwa reaksi feton dapat menghancurkan pengotor organic yang bersifat racun ${ }^{(135,148-150)}$.

Selain metoda tersebut, merkuri juga dapat dihilangkan dengan proses pertukaran ion ${ }^{(2,43}$, 151, 152). Sebelum proses ini dilakukan proses oksidasi terlebih dahulu. Proses pertukaran ion dilakukan dengan menggunakan beberapa jenis resin atau resin chelat tertentu. Sebagian resin yang sudah rusak atau tidak bias lagi beregenerasi harus diolah sebagai lembah berbahaya beracun. Karbon aktif granular sering digunakan pada proses pengolahan lanjutan air dengan tingkat keberhasilan yang bervariasi ${ }^{(153-158)}$. Untuk mendapakatkan hasil yang bagus untuk menghilangkan kandungan merkuri pada umumnya dilakukan dengan cara menggabungkan beberapa tahapan proses yaitu proses pertukaran ion dan proses adsorpsi dengan karbon aktif.

Proses pengolahan limbah berat $\mathrm{Hg}$ dilakuakn dengan menginjeksikan karbon ktif kedalam air beku terlebih dahulu. Zat polutan didalam air beku akan terdsorpsi oleh karbon aktif $^{(45,159-162)}$. Zat polutan dan lumpur akan dipisahkan dengan cara koagulasi dan sedimennya akan keluar berupa lumpur berwarna hitam. Untuk karbon aktif yang belum terpisah oleh proses sebelumnya dapat dihilangkan dengan proses filtrasi. Namun proses filtrasi kadang tidak efesien karena partikel kecilnya masih tetap bisa lolos saat dilakukan penyaringan. Untuk menghindari hal tersebut dapat dilakukan dengan cara memberikan koagulan Poly Aluminium Chloride serta pengontrolan proses yang ketat.

Salah satu keuntungan dari pengolahan dengan karbon aktif bubuk antara lain:

1. Fasilitas pengolahan dapat disesuaikan dengan alat yang sudah ada

2. Sangat ekonomis dalam keadaan darurat

3. Daya adsorpsinya besar karena luas permukaan dari karbon aktif yang luas

4. Kemungkinan ada gangguan dari organisme kecil

Selain itu proses ini juga memiliki kekurangannya diantara lain:

1. Cara pengerjaannya lebih sulit karena partikelnya yang sangat halus yang mudah bertebangan dan terbakar.

2. Karbon aktif yang telah bercampur dengan zar pengotor sangat sulit untuk beregenerasi.

3. Penyumbatan pada peralatan atau musim kemungkinan besar sehingga dibutuhkan pengontrol yang lebih sulit ${ }^{(163-167)}$.

Table 1. Spesifikasi karbon aktif butiran (Granular Activated Carbon, GAC)

\begin{tabular}{c|c}
\hline Item & Standar pemilihan \\
\hline Ukuran butiran & $8-32$ mesh $(2,302-0,495 \mathrm{~mm})$ lebih dari $95 \%$ \\
Methylene blue decoloration & $>150 \mathrm{mg} / \mathrm{g}$ \\
Iodine adsorption & $>1000 \mathrm{mg} / \mathrm{g}$ \\
Dry weight reduction & $<5 \%$ \\
$\mathrm{pH}$ & $4-11$ \\
Choride & $<0,5 \%$ \\
Lead $(\mathrm{Pb})$ & $<10 \mathrm{ppm}$ \\
\hline
\end{tabular}

Hubungan antara jumlah massa zat yang teradsorpsi oleh karbon aktif per massa karbon aktif yang diberikan, dengan konsentrasi adsorbate (misal zat organik), dalam air pada keadaan setimbang, secara empiris ditunjukkan oleh persamaan, Freundlich ${ }^{(22,168-172)}$ sebagai berikut:

$$
Y=\frac{X}{M}=K C^{1 / n}
$$

di mana $: \mathrm{Y}=$ Jumlah zat teradsorp per jumlah massa karbon aktif. 
$\mathrm{X}=$ Jumlah massa zat yang teradsorpsi.

$\mathrm{M}=$ Jumlah massa karbon aktif.

$\mathrm{C}=$ Konsentrasi zat polutan dalam air (disebut Adsorbate) pada keadaan setimbang $\mathrm{k}, \mathrm{n}=$ Konstanta.

ini

Hubungan kesetimbangan antara $\mathrm{X} / \mathrm{M}$ dengan $\mathrm{C}$ dapat dilihat pada grafik berikut

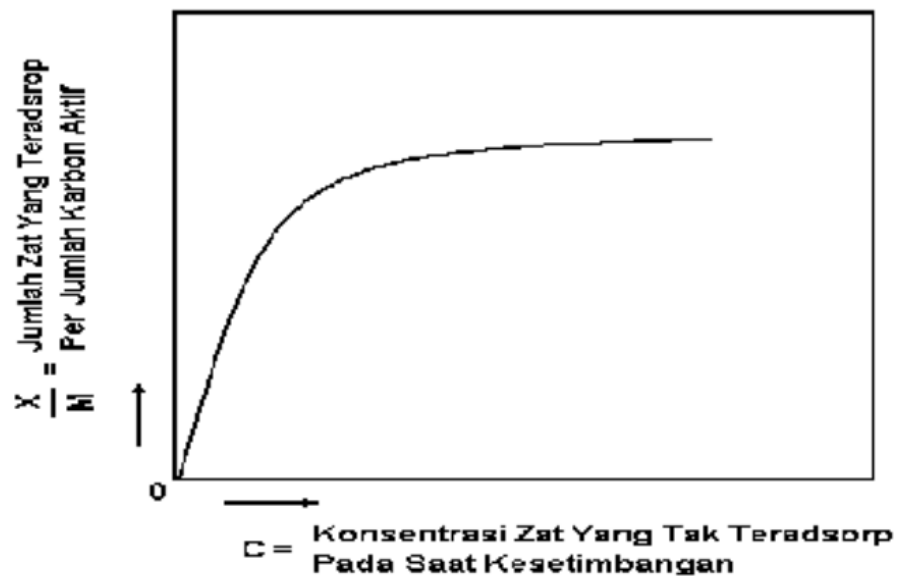

Gambar 4. Grafim hubungan antara zat yang teradsorpsi per jumlah karbon aktif dengan konsentrasi $C$ pada saat kesetimbangan.

Pengolahan air dengan cara adsorpsi satu tahap dengan anggapan bahwa karbon aktif sebagai adsorbent tidak larut atau tidak bereaksi dengan air atausolventnya ${ }^{(33-36,173)}$. Air baku dengan konsentrasi adsorbate (zat yang akan diadsorp) sebesar $\mathrm{Cn}$ dan laju alir Q, diturunkan konsentrasinya menjadi $\mathrm{C}_{1}$ (massa adsorbate per unit volume air baku) dengan laju penambahan karbon aktif M (massa/waktu). Jumlah massa zat yang teradsorpsi per jumlah massa karbon aktif akan naik dari Yn menjadi $Y_{1}$. Untuk operasi yang kontinyu maka jumlah adsorbate yang direduksi (diambil) dari air baku akan sama dengan jumlah yang di adsorp oleh karbon aktif. Persamaan matematiknya dapat dituliskan sebagai berikut :

$\mathrm{Q}\left(\mathrm{C}_{0}-\mathrm{C}_{1}\right)=\mathrm{M}\left(\mathrm{Y}_{1}-\mathrm{Y}_{0}\right)$.

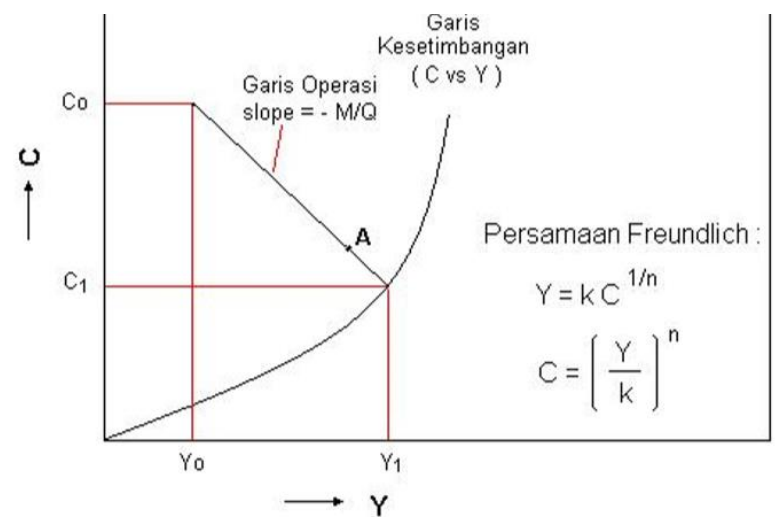


Gambar 5. Operasi adsopsi satu tahap

Jika dianggap bahwa untuk adsorbent yang masih baru, $\mathrm{Y}_{0}=0$, maka jika persamaan (1) disubstitusikan ke persamaan (2), didapatkan hasil sebagai berikut :

$$
\frac{M}{Q}=\frac{C_{0}-C_{1}}{K C_{1}^{1 / n}}
$$

Untuk adsorpsi yang baik, biasanya besarnya harga $\mathrm{n}$ antara 2 - 10; antara 1 - 2 untuk yang agak sulit; sedangkan untuk $n$ lebih kecil dari 1 adsorpsi sangat sulit di lakukan. Di samping itu besarnya harga $\mathrm{k}$ juga merupakan parameter yang penting untuk proses adsorpsi ${ }^{(174-176)}$.

Table 2.Parameter Adsorpsi Isotherm Freundlich untuk Adsprosi Merkuri ${ }^{(177,178)}$.

\begin{tabular}{c|c|c}
\hline Adsorbent & $\mathrm{K}$ & $1 / \mathrm{n}$ \\
\hline GAC & 4,68 & 3,16 \\
BPHC & 42,17 & 3,5 \\
Coal Fly Ash (pH 2,2) & 1,014 & 0,053 \\
Coal Fly Ash (pH 3,1) & 1,094 & 0,333 \\
Coal Fly ash (pH 3,1) & 1,230 & 0,361 \\
MHBB & 1,07 & 0,32 \\
\hline
\end{tabular}

Keterangan :

GAC $=$ Granular Activated Carbon (karbon aktif butiran)

BPHC $=$ Bicarbonate- treated Peanut Hull Carbon

MHBB = Modified Hardwickia Binata Bark

\section{KESIMPULAN}

Senyawa mercury (II) Nitrate merupakan suatu senyawa berupa padatan putih atau tidak berwarna yang dapat larut dalam air, aseton amoniak namun tidak dapat larut didalam alcohol. Senyawa ini berdampak buruk bagi tubuh karena akan terion menjadi $\mathrm{Hg}^{+}$dan akan merusak jaringan tubuh. Salah satu penanggulangan logam $\mathrm{Hg}$ pada pencemaran lingkungan dapat dilakukan dengan adsorpsi dengan karbon aktif. Permukaan karbon akan menyerap ion Hg.Mercury (II) Nitrate merupakan senyawa yang tidak dapat ditemukan di alam bebas. Perlu dilakukan sintesis terlebih dahulu dengan mereaksikan logam $\mathrm{Hg}$ dengan asam nitrat dengan suhu yang sangat tinggi. Mercury (II) nitrate memiliki titik lebur $79{ }^{\circ} \mathrm{C}, \Delta H=-743,1 \mathrm{kj} / \mathrm{mol}, \Delta G=$ $-625,8 \mathrm{kj} / \mathrm{mol}, \Delta S=200,7 \mathrm{~J} / \mathrm{molK}$ sehingga reaksi bersifat eksotermis.Mercury (II) Nitrat memiliki massa molar, densitas dan susceptibility magnetic yang mana nilainya berturut-turut $324,6 \mathrm{gr} / \mathrm{mol}, 4,3 \mathrm{gr} / \mathrm{cm}^{3}$, dan $-74,0 \times 10^{-6} \mathrm{~cm}^{3} / \mathrm{mol}$. Kalkulasi kecepatan rata-rata $\mathrm{Hg}\left(\mathrm{NO}_{3}\right)_{2}$ pada suhu $298 \mathrm{~K}$ kecepatan hanyut, konduktivitas termal yaitu 2,289 m/ s,1,769 V/pm, dan 8,3 W/m.K. Distribusi velositas yang dikalkulasikan pada suhu $300 \mathrm{~K}$ yaitu $28,6 \times 10^{-2} \mathrm{~m} / \mathrm{s}$. Berdasarkan analisis dengan Chem Draw Profesional 15.0 diperoleh total energy minimalisasi mimimum, perenggangan, dan Stretch-Bend pada suhu 300 Kyang nilainya berturut-turut yaitu $30.3182 \mathrm{kcal} / \mathrm{mol}, 1.4052$ dan -0.1016 . Disamping itu mercury (II) Nitarte digunakan sebagai bahan pembuatan bulu kempa, bahan pembuatan almogam gigi. 


\section{Reference}

1. The American mercury digest ; 1936. distinguished American mercury articles and stories which have been accorded wide acclaim [text]. New York, etc. ,: American mercury ,;

2. Miscellaneous Pamphlet Collection (Library of Congress). Address to the public by the editors of the Bristol Mercury, and Monmouthshire, South Wales, and West of England Advertiser, Monday, September 7, 1818. Bristol?: Browne and Manchee; 1818. 8 p. p.

3. Yotsukura N, Fischer HB, Sayre WW. Measurement of mixing characteristics of the Missouri River between Sioux City, Iowa, and Plattsmouth, Nebraska : measurement of longitudinal dispersion, transverse mixing, channel geometry, and transverse velocity distribution. Washington: Govt. Print. Off.; 1970. iv, 29 p. p.

4. Whitmore QR. Experimental investigation of temperature and velocity distribution about a rocket jet. Pasadena1948. v, 84 1. p.

5. West Virginia pulp and paper company. 1941. Industrial chemical sales division., Hassler JW. Active carbon, the modern purifier. New York,: West Virginia pulp and paper company; 1941.

6. Valière J-C. Acoustic particle velocity measurements using lasers : priniciples signal processing and applications. xi, 143 pages $\mathrm{p}$.

7. United States. Bureau of Mines. Mercury potential of the United States. Washington: Bureau of Mines; 1965. 376 p. p.

8. Suzuki T, Imura N, Clarkson TW. Advances in mercury toxicology. New York: Plenum Press; 1991. xxi, 490 p. p.

9. Suffet IH, McGuire MJ. 1980. Activated carbon adsorption of organics from the aqueous phase. Ann Arbor, Mich.: Ann Arbor Science.

10. Spivak LE, Angoff C. 1979. The American mercury reader : a selection of distinguished articles, stories, and poems published in the American mercury during the past twenty years. 1st AMS ed. New York: AMS Press; 378 p. p.

11. Spivak LE, Angoff C. The American mercury reader; a selection of distinguished articles, stories. Philadelphia,: The Blakiston company; 1944. 5 p.l., -378 p. p.

12. 15 down home country blues classics [sound recording]. El Cerrito, CA: Arhoolie,; 1996.

13. 1949-50-51 Ford/Mercury owners magazine. Midwest City, OK: Shoebox Ford Enterprises; 1993. p. v.

14. Curry JA, Webster PJ. 1999. Thermodynamics of atmospheres and oceans. San Diego, Calif. ; London: Academic Press; xvii, 471 s. p.

15. Schirmer W, Scheel H, Akademie der Wissenschaften der DDR. Klasse Chemie., Akademie der Wissenschaften der DDR. Zentralinstitut für Physikalische Chemie1981.. Adsorption an Zeolithen. Berlin: Akademie-Verlag; 71 p. p.

16. The 1952 Mercury Monterey, manufacutred by the Lincoln-Mercury Division of Ford Motor Company [graphic] 1952.

17. 1963 Ford Galaxie and 1962-63 Mercury Monterey. Shop manual supplement. Dearborn, Mich.: Service Dept., Ford Motor Co.; 227 p. p.

18. Ford Motor Company. 1979.Parts and Service Division. Training and Publications Department. 1980 Car shop manual. Dearborn, Mich.: Ford Parts and Service Division, Training and Publications Dept.;

19. Hartley JR, Kaleth J, Thomas R. 1987. 21st century planets suite ; Scientific illustration [sound recording]. London: Cavendish Music,; 1987.

20. Cronkite W. The 60 greatest old-time radio shows of the 20th century [sound recording]. Schiller Park, IL: Radio Spirits,; 1999.

21. Scott $\mathrm{CH}$. Aboriginal autonomy and development in northern Quebec and Labrador. Vancouver: UBC Press; 2001. xii, 436 p. p. 
22. George, Humphreys D, Story E, Printed Ephemera Collection (Library of Congress). [Address of the Lords and Commons to His Majesty on the present state of America, etc. February 11, 1775]. Philadelphia: Printed by Enoch Story and Daniel Humphreys; 1775. 1 sheet ( p.) p.Sherman JD, Vermeulen T, Anderson RA, American Institute of Chemical Engineers. A

23. dsorption and Ion Exchange Program Committee. Adsorption and ion exchange -- progress and future prospects. New York, N.Y.: American Institute of Chemical Engineers; 1984. 124 p. p.

24. Said Ni. 2010;Metoda Penghilangan Logam Merkuri Di Dalam Air Limbah Industri. Pusat Teknologi Lingkungan, Badan Pengkajian Dan Penerapan Teknologi. ;6:12.

25. Quirke N. 2006. Adsorption and transport at the nanoscale. Boca Raton: CRC/Taylor \& Francis; 186 p. p.

26. Pritchard D. 1990 Air patterns [sound recording]. Pasadena, Calif.: Molecular Music,;:

27. Smíšek M, Černý S. Active carbon: manufacture, properties and applications. Amsterdam, New York,: Elsevier Pub. Co.; 1970. xii, 479 p. p.

28. Perrich JR. 1981. Activated carbon adsorption for wastewater treatment. Boca Raton, Fla.: CRC Press; 252 p. p.

29. Parrish WP. 1952. The influence of the $\mathrm{pH}$ of active carbon on the removal of chlorine from solution. Washington, 42 1. p.

30. Amiji MM, Cook TJ, Mobley WC. Applied physical pharmacy. Second edition. ed. xii, 270 pages $\mathrm{p}$.

31. Barton AFM, Haulait-Pirson MC. 1984. Alcohols with water. 1st ed. Oxford ; New York: Pergamon; xix, 438 p. p.

32. Boccaccini AR, Brauer DS, Hupa L, Royal Society of Chemistry (Great Britain). Bioactive glasses : fundamentals, technology and applications. xix, 530 pages $\mathrm{p}$.

33. Clever HL. Argon. 1984.1st ed. Oxford ; New York: Pergamon Press;.xviii, 331 p. p.

34. Fitzgerald GB, Govind N, American Chemical Society. Division of Computers in Chemistry. Applications of molecular modeling to challenges in clean energy. xi, 245 pages $p$.

35. Jourdan F, Mark DF, Verati C. Advances in ${ }^{40} \mathrm{Ar} /{ }^{3} \mathrm{Ar}$ dating : from archaeology to planetary sciences. vi, 378 pages p.

36. Königsberger E, Königsberger L. Biomineralization : medical aspects of solubility. Chichester, England ; 2006.Hoboken, NJ: J. Wiley; xii, 284 p. p.

37. Mitra AK, Lee CH, Cheng K. 2014.Advanced drug delivery. Hoboken, N.J: Wiley; xvi, 514 p. p.

38. Miyamoto H, Salomon M, Clever HL. 1983. Alkaline earth metal halates. 1st ed. Oxford ; New York: Pergamon Press; xx, 332 p. p.

39. Tomlinson E, Regosz A1985.. Antibiotics. 1st ed. Oxford Oxfordshire ; New York: Pergamon Press; v. $<1>$ p.

40. Mencken HL, Nathan GJ, 1923Printed Ephemera Collection (Library of Congress). [The American mercury : publisher's prospectus and three editorials by H.L. Mencken]. New York, N.Y.: Alfred A. Knopf;. 4 pieces. p.

41. Mencken HL, Nathan GJ. 1984.The American mercury. Blauvelt, N.Y.: Freedeeds Books; p. v.

42. Mencken HL, Nathan GJ. 1924. The American mercury. New York: Knopf;

43. Ma YH, American Institute of Chemical Engineers. 1983Adsorption and Ion Exchange Committee. Adsorption and ion exchange--'83. New York, N.Y.: American Institute of Chemical Engineers;. 85 p. p.

44. LeVan MD, Knaebel KS, Sircar S, Wankat PC, Bolden WB. 1988.Adsorption and ion exchange : fundamentals and applications. New York, N.Y.: American Institute of Chemical Engineers; 176 p. p.

45. Hoboken, N.J.: Wiley;.Korpela SA. 2011Principles of turbomachinery. xvi, 457 p. p. 
46. King JG, MacDougall D, Gilmour H. 1938.The production of active carbon from bituminous coal. London,: H.M. Stationery off. printed by Eyre and Spottiswoode limited; vi, 55 p. incl. illus., tables, diagrs. 2 pl. (1 fold.) p.

47. Canada. Environment Canada., Canada. National Guidelines and Standards Office. Canadian water quality guidelines for the protection of aquatic life : nitrate ion. Ottawa: National Guidelines and Standards Office, Environment Canada; 2003. xii, 115 p. p.

48. The gambling thermometer or Fundamental guide to stock-jobbing [graphic]. England: By J. Johnson, 98 Cheapside,; 1814.

49. H.S. Tanner; 1825.The mariners atmospherical register; or, Weather book: comprehended in thirteen sheets, constructed for recording the variations of the marine barometer and thermometer; the latitude, longitude, direction of the wind, state of the weather, and other useful remarks for every day in the year, and for a period of three years, with rules for judging the change and alteration of the weather by the barometer, by which a correct knowledge may be acquired of the approach of gales of wind and storms at sea. Illustrated by some practical remarks and examples demonstrating the great utility of a work of this description. Philadelphia,:

50. Mason Brothers; 1857.The New York almanac and yearly record for ... 1857-58 : containing, in addition to the calendar, a record of the state of the thermometer for every day in the year ... a complete diary for the year ... with a great amount of tables, and useful information generally. New York:

51. Help us make it hot for the Kaiser--1917.Buy your stamps here now and see the thermometer go up--War Savings Stamps issued by the United States Government An idle quarter is a slacker quarter--Invest in Thrift Stamps now and save some lad's life in no man's land [graphic]

52. The 1952 Lincoln Capri, manufactured by the Lincoln-Mercury Division of Ford Motor Company [graphic].

53. Mittal KL, American Chemical Society. 1975.Division of Colloid and Surface Chemistry., American Chemical Society. Adsorption at interfaces : papers from a symposium honoring Robert D. Vold and Marjorie J. Vold sponsored by the Division of Colloid and Surface Chemistry at the 167th meeting of the American Chemical Society, Los Angeles, Calif., April 2-5, 1974. Washington: American Chemical Society; xii, 290 p. p.

54. The 22nd international conference on miniaturized systems for chemistry and life sciences. 2018 edition. ed. pages $\mathrm{cm}$ p.

55. Jankowska H, Świątkowski A, Choma J, Kemp TJ. 1991.Active carbon. New York: E. Horwood; 280 p. p.

56. GA: ASHRAE; 2010American Society of Heating Refrigerating and Air-Conditioning Engineers. 2010 Ashrae Handbook : Refrigeration. Inch-pound ed. Atlanta,.

57. Boykin DW. $1991{ }^{17} \mathrm{O}$ NMR spectroscopy in organic chemistry. Boca Raton, Fla.: CRC Press;. 325 p. p.

58. González Pérez JMa, Matilla Hernández A, Niclós Gutiérrez J. 11th European Biological Inorganic Chemistry Conference : EUROBIC 11. 1 CD-ROM p.

59. Kluger J, Time Inc. 2011.Home Entertainment. 100 new scientific discoveries : fascinating, unbelievable and mind-expanding stories. New York, N.Y.: TIME Books; 112 p. p.

60. Padwa A. 1984. 1,3-dipolar cycloaddition chemistry. New York: Wiley;

61. Royal Society of Chemistry. 2004.100 years of physical chemistry : a collection of landmark papers. Cambridge: Royal Society of Chemistry; vii, 376 p. p.

62. Simpkins NS, Royal Society of Chemistry (Great Britain). 1989.100 modern reagents. Nottingham: Moss Pub; ix, 203 pages p. 
63. Strom ET, Rasmussen SC, American Chemical Society. 2011.Division of the History of Chemistry. 100+ years of plastics : Leo Baekeland and beyond. Washington, DCNew York?: American Chemical Society Distributed in print by Oxford University Press; xi,193 p. p.

64. Tamao Kh. 21-seiki no yūki keiso kagaku : 2004.kinōsei busshitsu kagaku no hōko. Tōkyō: Shīemushī Shuppan; viii, 316 p. p.

65. Brunsmann PW, Paalman AC. 1971 [An improved modification of the diphenylcarbazonemercury (II) nitrate reaction on barbiturates, applied to the toxicologic study of blood on thinlayer chromatography]. Pharm Weekbl.;106(52):933-7.

66. Bruenn SW. 1969.A theoretical investigation of the random velocity distribution of interstellar gas clouds [Thesis]. New York?: Columbia University.;

67. Breck DW, Sherman JD, American Institute of Chemical Engineers. 1978.Adsorption and ion exchange separations. New York: American Institute of Chemical Engineers; vi, 125 p. p.

68. Boyk S, Hass HB. 1946.Active carbon from chlorinated coal. n. p.,

69. Borg K. Alkyl mercury poisoning in terrestrial Swedish wildlife. Stockholm,: Svenska jägareförbundet; 1969. (1), 301-79 p., (2) leaves of plates. p.

70. Boiling Point: How Politicians, Big Oil and Coal, Journalists and Activists Are Fueling the Climate Crisis--and What We Can Do to 2004Avert Disaster (Book). Booklist.;100(22):1880-.

71. Boiling Point: How Politicians, Big Oil and Coal, Journalists and Activists Have Fueled the Climate Crisis -- And What We Can Do to Avert Disaster (Book). Publishers Weekly. 2004;251(24):54-.

72. Boiling Point: How Politicians, Big Oil and Coal,Journalists, and Activists Have Fueled the ClimateCrisis--and What We Can Do to Avert Disaster (Book). Kirkus Reviews. 2004;72(11):525-.

73. Boiling Point: How Politicians, Big Oil and Coal, Journalists, and Activists are Fueling the Climate Crisis--And What We Can Do to Avert Disaster. Choice: Current Reviews for Academic Libraries. 2005;42(7):1264-.

74. Boiling Point. Publishers Weekly. 2010;257(43):29-.

75. Bonds Hit Boiling Point Thanks to ECB. Wall Street Journal (Online). 2015:1.

76. Grunwald GD. A comparative study of topological and geometrical parameters in estimating normal boiling point and octanol/water partition coefficient. Journal of Chemical Information \& Computer Sciences. 1996;36(6):1054-60.

77. A.A. Knopf 1924-Mar. 1935. American Mercury.

78. N.Y.,: 1943.The American mercury reader; a selection of distinguished articles, stories. New York, The American mercury; 208 p. p.

79. The American mercury digest; distinguished American mercury articles and stories which have been accorded wide acclaim. New York, etc.,: The American mercury, inc.; 1936.

80. The ambassador of commerce 1927.

81. The ambassador of commerce for the city and port of Liverpool and the adjoining boroughs. Liverpool,1924.

82. The American mercury. Hartford, Conn.: Barlow and Babcock; 1784. p. v.

83. 35 pressure indicators. [Contoocook, $\mathrm{NH}$ ].

84. 20 raggae classics [sound recording]. London: Trojan,; 1984.

85. 20 reggae classics [sound recording]. London: Trojan Records,; 1984.

86. 12 inches of Virgin [sound recording]. Beverly Hills, CA: Virgin,; 1988.

87. The 24 hour woman music from The Shooting Gallery motion picture [sound recording]. Miami, Fl.: WEA Latina,; 1999.

88. 120 talonz 2003. [sound recording]. S.1.: A. Cipher Recordings,;

89. Copyright Collection (Library of Congress). The 100. Contents under pressure2014. 1 videocassette of (Digital Betacam) (60 min.) p. 
90. Frank W. 2000Cawood and Associates. 1,001 prescription drugs : side effects, dangerous combinations, and natural healing alternatives. Peachtree City, GA: Frank W. Cawood Pub.;. 388 p. p.

91. Hampton B, Collins S, Hicks C, Gallagher D, Mitchell B, Rosman M, et al. 7th heaven. The seventh season [two-dimensional moving image].

92. Melki SA, Azar DT. 2006.101 pearls in refractive, cataract, and corneal surgery. 2nd ed. Thorofare, NJ: SLACK Inc.; xiii, 194 p. p.

93. Milk or Sugar in Your Low-Viscosity-Liquid Dynamic? 2016Scientists Seek the Perfect Cup of Coffee. Wall Street Journal (Online).:1.

94. Vanishing Viscosity Method: Solutions to Nonlinear Systems. Sci-Tech News. 2017;71(2):18-

95. Gitis M. 20180n the interpretation of shear viscosity ultrasonic measurements. Ultrasonics.;93:1-6.

96. Kampf N, Wachtel EJ, Zilman A, Ben-Shalom N, Klein J. 2018Anomalous viscosity-time behavior of polysaccharide dispersions. The Journal of chemical physics.;149(16):163320.

97. Kim DS, Lee JK. 2019Effect of Slurry Viscosity and Dispersant Agent on the Sintering of 3YTZP Ceramics Fabricated by Slip Casting. Journal of nanoscience and nanotechnology.;19(2):1118-21.

98. Leuzinger S, Steingotter A, Nystrom L.2018. Viscosity of Cereal beta-Glucan in the Gastrointestinal Tract. Chimia.;72(10):733-5.

99. Ramon Mendo Escoda J, Areal Guerra R, Alberto Hernaacutendez L. 2001A Method for the Non-Destructive Analysis of Paper Based on Reflectance and Viscosity. Restaurator.;22(4):187.

100. Schuurmann G. 1997Development of both linear and nonlinear methods to predict the liquid viscosity at 20 degrees $C$ of organic compounds. Journal of Chemical Information \& Computer Sciences.;37(6):1122-8.

101. Yuan H, Cheng H, Liu P-sA. Case study on digital library's user viscosity in Chongqing University Library. Library Management. 2012;33(3):184-94.

102. Zhang Y, Moins S, Coulembier O, Seveno D, De Coninck J. Capillary rise of polydimethylsiloxane around a poly(ethylene terephthalate) fiber versus viscosity: Existence of a sharp transition in the dynamic wetting behavior. Journal of colloid and interface science. 2018;536:499-506.

103. Melting point. Times Higher Education Supplement. (1128):13.

104. South Africa's Melting Point. New York Times Book Review.30.

105. Chemistry, biochemistry and pharmacology of hydrogen sulfide. pages $\mathrm{cm} \mathrm{p}$.

106. CN, Blowes DW, 1992.American Chemical Society. Division of Geochemistry., American Chemical Society. Meeting. Environmental geochemistry of sulfide oxidation : developed from a symposium sponsored by the Division of Geochemistry, Inc., at the 204th National Meeting of the American Chemical Society, Washington, DC, August 23-28, Washington, DC: American Chemical Society; 1994. xiv, 681 p. p.

107. Friedrich G, Herzig PM, 1985Deutsche Mineralogische Gesellschaft., Gesellschaft Deutscher Metallhütten- und Bergleute., Society for Geology Applied to Mineral Deposits. Base metal sulfide deposits in sedimentary and volcanic environments : proceedings of the DMG-GDMBSGA-meeting, Aachen,. Berlin ; New York: Springer-Verlag; 1988. viii, 290 p. p.

108. Hwang J-Y, Minerals Metals and Materials Society. 2013Extraction and Processing Division., Minerals Metals and Materials Society. Annual Meeting. Characterization of minerals, metals, and materials : proceedings of a symposium. xix, 574 pages $p$.

109. Inoue Yz. Anteikei saishū shobunjō ni okeru kōnōdo ryūka suiso hassei kikō no kaimei narabini sono kankyō osen bōshi taisaku ni kansuru kenkyū. Tsukuba-shi: Kokuritsu Kankyō Kenkyūjo; 2005. vi, 74 p. p. 
110. Ito K. Copper zinc tin sulfide-based thin film solar cells. xii, 421 pages $\mathrm{p}$.

111. Roesky HW. Efficient preparations of fluorine compounds. xx, 454 pages p.

112. Taillefert M, Rozan TF. 2002Environmental electrochemistry : analyses of trace element biogeochemistry. Washington, D.C.: American Chemical Society;. xii, 412 p. p.

113. Tsigdinos GA, Tsigdinos GA, 1978. Moh Gn. Aspects of molybdenum and related chemistry. Berlin; New York: Springer-Verlag;. 159 p. p.

114. Yoshikawa T, Naito Y. 2011.Gas biology research in clinical practice. Basel: Karger; vii, 148 pages $\mathrm{p}$.

115. Advanced thermodynamics engineering. 1st edition. ed. pages $\mathrm{cm} \mathrm{p}$.

116. Bergmann PG, De Sabbata V. 2002.Advances in the interplay between quantum and gravity physics. Dordrecht ; Boston: Kluwer Academic Publishers; viii, 554 p. p.

117. Chen L, Sun F. Advances in finite time thermodynamics : analysis and optimization. Hauppauge, N.Y.: Nova Science Publishers; 2004. xxxviii, 240 p. p.

118. Chiotti P. 1981. The Actinide binary alloys. Vienna: International Atomic Energy Agency; 275 p. p.

119. Clegg B, Ball P, Rawlings S. 30-second physics : the 50 most fundamental concepts in physics, each explained in half a minute. 160 pages $p$.

120. Ellison MD, Schoolcraft TA, 2008.American Chemical Society. Advances in teaching physical chemistry. Washington, D.C.: American Chemical Society; ix, 332 p. p.

121. Fosdick R, Carlson DE, Chen Y-C. 2000.Advances in continuum mechanics and thermodynamics of material behavior : in recognition of the 60th birthday of Roger L. Fosdick. Dordrecht ; Boston: Kluwer Academic Publishers; 436 p. p.

122. Fuger J. 1992.The Actinide aqueous inorganic complexes. Vienna: International Atomic Energy Agency; 224 p. p.

123. Moore MK, Ledesma EB, American Chemical Society. Division of Industrial and Engineering Chemistry. Academia and industrial pilot plant operations and safety. ix, 97 pages $p$.

124. Rau U, Abou-Ras D, Kirchartz T. Advanced characterization techniques for thin film solar cells. Weinheim, Germany: Wiley-VCH; 2011. xxxvi, 547 p. p.

125. The American manufacturer. Pittsburgh Pa.: W.B. Conway. p. v.

126. [Advertisements and labels for medicines and health products submitted for copyright, 18391884 1840-1869]. 90 pieces $\mathrm{p}$.

127. Huang L, Zhongguo di zhi ke xue yuan. 1992.Xizang Gaoyuan di ke jie gou yu su du fen bu te zheng. Beijing di 1 ban. ed. Beijing: Di zhi chu ban she : Xin hua shu dian zong dian ke ji fa xing suo jing xiao; ix, 122 p. p.

128. Hegge Zijnen BGvd. 1924Measurements of the velocity distribution in the boundary layer along a plane surface. Delft,: Gedrukt bij J. Waltman, jr.;. 6 p.l., 48 p. p.

129. Hassler JW. Active carbon. Brooklyn,: 1951.Chemical Pub. Co.; vi, 384 p. p.

130. Gunkel D. Alternative energy sources. Detroit: Greenhaven Press; 2006. 204 p. p.

131. Gu B, Coates JD. Perchlorate : 2006environmental occurrence, interactions, and treatment. New York: Springer;. xii, 411 p. p.

132. Gonzalez D, New Dallas Angeles. The desert wind [sound recording]. S.1.: Silkheart Records,; 1989.

133. Hem JD, American Chemical Society. 1971Division of Water Air and Waste Chemistry. Nonequilibrium systems in natural water chemistry; a symposium sponsored by the Division of Water, Air, and Waste Chemistry of the American Chemical Society at Houston, Texas, February 24-25, 1970. Washington,: American Chemical Society;. x, 342 p. p.

134. Kothny EL, American Chemical Society. 1973.Division of Water Air and Waste Chemistry. Trace elements in the environment. Washington,: American Chemical Society; ix, 149 p. p. 
135. American Chemical Society. Division of Water Air and Waste Chemistry. Preprints of papers presented at ... national meeting. Pittsburgh, Pa.: American Chemical Society. p. v.

136. American Chemical Society. ,1963Division of Water Air and Waste Chemistry. [from old catalog]. American Chemical Society fiftieth anniversary of Division of Water and Waste Chemistry. Washington.

137. Manahan SE. 1990Hazardous waste chemistry, toxicology, and treatment. Chelsea, Mich.: Lewis Publishers; xiii, 378 p. p.

138. Sosis MB. 1974.The electronic G-factors of moltensodium-sodium chloride solutions [Ph D]: University of Chicago;

139. Sood A, Cheaito R, Bai T, Kwon H, Wang Y, Li C, et al.2018. Direct Visualization of Thermal Conductivity Suppression Due to Enhanced Phonon Scattering Near Individual Grain Boundaries. Nano letters.;18(6):3466-72.

140. Somes RG, Jr. 1992 Identifying the ptilopody (feathered shank) loci of the chicken. The Journal of heredity.;83(3):230-4.

141. Sobecki J, Boonjing V, Chittayasothorn S. 2014.Advanced approaches to intelligent information and database systems. New York: Springer;. x, 366 pages p.

142. Snyder WH, 3rd. 1988Popliteal and shank arterial injury. The Surgical clinics of North America:;68(4):787-807.

143. Tian F, Song B, Chen X, Ravichandran NK, Lv Y, Chen K, et al. 2018.Unusual high thermal conductivity in boron arsenide bulk crystals. Science.;361(6402):582-5.

144. Thurston AJ, Rastorfer J, Burian H, Beasley AW. 1989. The Flek-shin: a composite material for use in flexible shank below-knee prostheses. Prosthetics and orthotics international.;13(2):979.

145. Thunell S.1976. Koagulation : koagulationsdiagnostik, blödningssjukdomar. Lund: Studentlitt.;. 137 p. p.

146. Thottathil S, Thomas S, Kalarikkal N, Rouxel D. Advanced polymeric materials for sustainability and innovations [text].

147. Thottathil S, Thomas S, Kalarikkal N, Rouxel D. Advanced polymeric materials for sustainability and innovations. pages $\mathrm{cm} \mathrm{p}$.

148. Akademie der Wissenschaften der DDR. 1978.Zentralinstitut für Physikalische Chemie., Scheel H, Akademie der Wissenschaften der DDR. 20 Jahre Zentralinstitut für Physikalische Chemie : Festkolloquium. Berlin: Akademie-Verlag; 75 p. p.

149. Sonntag H, Strenge K. C 1972oagulation and stability of disperse systems. Jerusalem,New York,: Israel Program for Scientific Translations;Halsted Press;. x, 139 p. p

150. Sonntag H, Strenge K1970. Koagulation und Stabilität disperser Systeme. Berlin,: Deutscher Verlag der Wissenschaften;. 173 p. p.

151. mphd aslam SR, Masood 2013Alam Adsorpsi Of $\mathrm{Hg}$ (II) from aqueous Solution Using adulsa (Justicia Adhatoda) Leaves Powder: Kinetic and Aquilibrium Studies. hindawi pulishing Corporation Journal of chemestry.;:11.

152. Minnesota Pollution Control Agency. 2007Air quality in Minnesota : challenges and opportunities : 2007 report to the Legislature. St. Paul, Minn.: Minnesota Pollution Control Agency;.

153. Dick SJ, United States. 2007.National Aeronautics and Space Administration. History Office. America in space : NASA's first fifty years. New York: Abrams;. 351 p. p.

154. Davis BH, Occelli ML. 2007Fischer-Tropsch synthesis, catalysts and catalysis. 1st ed. Amsterdam ; Boston: Elsevier;. ix, 420 p. p.

155. Davidson HW. 1968.Manufactured carbon. 1st ed. Oxford, New York,: Pergamon Press; ix, 111 p. p. 
156. Dakovic M, Popovic Z. 2007 (Nitrato-kappaO)bis(pyridine-2-carboxamidekappa2N1,O)mercury(II) nitrate. Acta crystallographica Section C, Crystal structure communications.;63(Pt 12):m557-9.

157. Dąbrowski A. 1999Adsorption and its applications in industry and environmental protection. Amsterdam ; New York: Elsevier;.

158. Copyright Collection (Library of Congress). 1993. The American space odyssey. Vol. 2, Voyage of Friendship 7 (Mercury 3). United States: s.n.; 1 videocassette of (VHS) p.

159. Karge HG, Weitkamp J. Adsorption and diffusion. Berlin: Springer; 2008. xiii, 400 p. p.

160. Kalarikkal N, Raneesh B, Nair AK, James J. Plasma and fusion science : from fundamental research to technological applications. xxii, 445 pages $\mathrm{p}$.

161. International Astronomical Union. Symposium (330th : 2017 : Nice France), Recio-Blanco A, De Laverny P, Brown AGA, Prusti TJ. 2017Astrometry and astrophysics in the Gaia sky : proceedings of the 330th Symposium of the International Astronomical Union held in Nice, France, April 24-28, xxviii, 418 pages p.

162. Idziak A, Dubiel R. Geophysics in mining and environmental protection. xii, 136 pages p.

163. Copyright Collection (Library of Congress). The American space odyssey. Vol. 1, Freedom 7 (Mercury 1). United States: s.n.; 1993. 1 videocassette of (VHS) p.

164. Copyright Collection (Library of Congress). Alan Jackson, livin', lovin' and rockin' that jukebox1993. 1 videocassette of (VHS) (ca. $28 \mathrm{~min}$.) p.

165. Comesaña DFn. Scan-based sound visualisation methods using sound pressure and particle velocity [textPh D]: University of Southampton; 2014.

166. Che M, Bond GC, Tench AJ. Adsorption and catalysis on oxide surfaces : proceedings of a symposium, Brunel University, Uxbridge, June 28-29, 1984. Amsterdam ; New YorkNew York, NY: Elsevier ;Distributors for the U.S. and Canada, Elsevier Science Pub. Co.; 1985. xviii, 442 p. p.

167. Burchell TD. 1999.Carbon materials for advanced technologies. Amsterdam ; New York: Pergamon; xvii, 540 p. p

168. Friedrich CM1952.. A numerical difference equation method for determining velocity distribution in coaxial jets. Pittsburgh, 52 1. p.

169. Flank WH, 1980.American Chemical Society. Division of Industrial and Engineering Chemistry. Adsorption and ion exchange with synthetic zeolites : principles and practice : based on a symposium sponsored by the Division of Industrial and Engineering Chemistry at the 180th meeting of the American Chemical Society, San Francisco, California, August 25-26, 1980. Washington, D.C.: American Chemical Society; x, 293 p. p.

170. ezraneti r. 2016. Pengaruh Merkuri Nitrat Dengan Konsentrasi Berbeda Terhadap Benih Ikan Kakap Putih (Lates Calcarifer Bloch): Histologi Insang. Acta Aquatica.;3:1:4.

171. Erickson RR. The third and fourth moments of the local stellar velocity distribution $[\mathrm{Ph} \mathrm{D}]:$ University of Chicago; 1974.

172. Zainul, R. (2016, December 18). Design and Modification of Copper Oxide Electrodes for Improving Conversion Coefficient Indoors Lights (PV-Cell) Photocells. https://doi.org/10.31227/osf.io/pgn84

173. Zainul, R. (2016, December 18). Design and Modification of Copper Oxide Electrodes for Improving Conversion Coefficient Indoors Lights (PV-Cell) Photocells. https://doi.org/10.31227/osf.io/pgn84

174. Zainul, R. (2016, September 24). Determination of the half-life and the quantum yield of $\mathrm{ZnO}$ semiconductor photocatalyst in humic acid. https://doi.org/10.31227/osf.io/e8a9x

175. Febriani, S. S., Yolanda, T., Arianti, V. A., \& Zainul, R. (2018, September 2). A Review Solid Stated : Principles and Methode. https://doi.org/10.31227/osf.io/7us4x 
176. Liza, Y. M., Yasin, R. C., Maidani, S. S., \& Zainul, R. (2018, September 29). SOL GEL : PRINCIPLE AND TECHNIQUE (A REVIEW). https://doi.org/10.31227/osf.io/2cuh8

177. Zainul, R. (2016, November 19). Effect of Temperature and Particle Motion against the ability of ZnO Semiconductor Photocatalyst in Humic Acid. https://doi.org/10.31227/osf.io/wnygb

178. Dinata, A. A., Rosyadi, A. M., Hamid, S., \& Zainul, R. (2018, August 31). A Review CHEMICAL VAPOR DEPOSITION : PROCESS AND APPLICATION. Https://Doi.Org/10.31227/Osf.Io/Yfeau

179. Putri, D. F., Ritonga, H. M., Murdiati, V., \& Zainul, R. (2018, August 31). A REVIEW WHAT IS HYDROTHERMAL ?. https://doi.org/10.31227/osf.io/dm56c

180. Awalliyah, A., Ikhwan, H., Nugiasari, V., \& Zainul, R. (2018, August 31). A REVIEW PRINSIP DASAR MILLING DALAM SINTESIS MATERIAL. https://doi.org/10.31227/osf.io/9xsqe

181. Candani, D., Ulfah, M., Noviana, W., \& Zainul, R. (2018, September 1). A Review Pemanfaatan Teknologi Sonikasi. https://doi.org/10.31227/osf.io/uxknv

182. Fatimah, P., Jumalia, R., Novianti, E. R., \& Zainul, R. (2018, August 31). A REVIEW Teknik Blended : Prinsip dan Dasar-Dasar. https://doi.org/10.31227/osf.io/tm2w4

183. Zainul, R., Oktavia, B., Dewata, I., \& efendi, j. (2017, February 4). Studi Dinamika Molekular dan Kinetika Reaksi pada Pembelahan Molekul Air untuk Produksi Gas Hidrogen. https://doi.org/10.31227/osf.io/876s3

184. Zainul, R., Alif, A., Aziz, H., Arief, S., \& s. (2015, October 22). Photoelectrosplitting Water Mechanism at Carbon Electrode Surface using Indoor lights. https://doi.org/10.31227/osf.io/vcxq8

185. Zainul, R., Alif, A., Aziz, H., Arief, S., \& s. (2015, October 22). Photoelectrosplitting Water Mechanism at Carbon Electrode Surface using Indoor lights. https://doi.org/10.31227/osf.io/vcxq8

186. M., Yani, S. R., \& Zainul, R. (2017, September 4). Aktivasi Tanah Napa dan Pengaruhnya Terhadap Adsorpsi Ion Timbal (II)/ Pb2+. https://doi.org/10.31227/osf.io/ps523

187. P, O. M., A, L. G., S, A. Y. M., \& Zainul, R. (2018, September 1). A Review Grinding : Teknik dan Prinsip Dasar pada Pengolahan Material. https://doi.org/10.31227/osf.io/trv4q

188. H., Sanjaya, H., \& Zainul, R. (2016, August 30). Synthesis and Electrical Properties of ZnOITO and Al-ITO thin Film by Spin Coating Technique Through Sol Gel Process. https://doi.org/10.31227/osf.io/unrt4

189. M., Sanjaya, H., \& Zainul, R. (2015, December 30). Characterization of napa soil and adsorption of $\mathrm{Pb}$ (II) from aqueous solutions using on column method. https://doi.org/10.31227/osf.io/t8fh9

190. chaidir, z., Fadjria, N., A., \& Zainul, R. (2016, December 5). ISOLATION AND MOLECULAR IDENTIFICATION OF FRESHWATER MICROALGAE IN MANINJAU LAKE WEST SUMATERA. https://doi.org/10.31227/osf.io/nbcuf

191. chaidir, z., Zainul, R., Nurakhbari, D., \& Salim, M. (2016, September 24). Optimization of Spirulina Platensis Culture for Antioxidant Production. https://doi.org/10.17605/OSF.IO/FD6E4

192. Zainul R, Oktavia B, Dewata I, Efendi J. 2018, Thermal and Surface Evaluation on The Process of Forming a Cu2O/CuO Semiconductor Photocatalyst on a Thin Copper Plate. Proc. IOP Conference Series: Materials Science and Engineering, 335:012039: IOP Publishing

193. Zainul R, Alif A, Aziz H, Arief S, Dradjad S, Munaf E. 2015. Design of photovoltaic cell with copper oxide electrode by using indoor lights. RESEARCH JOURNAL OF PHARMACEUTICAL BIOLOGICAL AND CHEMICAL SCIENCES 6:353-61 
194. Mawardi M, Deyundha D, Zainul R. Characterization of PCC Cement by Addition of Napa Soil from Subdistrict Sarilamak 50 Kota District as Alternative Additional Material for Semen Padang. Proc. IOP Conference Series: Materials Science and Engineering, 2018, 335:012034: IOP Publishing

195. Anhar A, Sumarmin R, Zainul R. 2016. Measurement of Glycemic Index of West Sumatera Local Rice Genotypes for Healthy Food Selection.https://doi.org/10.31227/osf.io/tgy8h

196. Zainul R, Dewata I. 2015. Determination of pH-BOD-COD and degradation in batang arau watersheds at Padang city $10.31227 /$ osf.io/efdzj.

197. Zainul R, Alif A, Aziz H, Arief S. 2015. DISAIN GEOMETRI REAKTOR FOTOSEL CAHAYA RUANG. Jurnal Riset Kimia 8:131https://doi.org/10.25077/jrk.v8i2.230

198. Zainul R, Alif A, Aziz H, Arief S, Darajat S. 2015. Modifikasi dan Karakteristik IV Sel Fotovoltaik Cu2o/Cu-Gel Na2so4 Melalui Iluminasi Lampu Neon. EKSAKTA 2:50

199. Yasthopi A. 2015. Photoelectrosplitting water for hydrogen production using illumination of indoor lights. Journal of Chemical and Pharmaceutical Research 7:246-56

200. Zainul R. 2015. Disain dan Modifikasi Kolektor dan Reflektor Cahaya pada Panel Sel Surya Al/Cu2O-Gel Na2SO4.http://repository.unp.ac.id/id/eprint/610

201. Mawardi Anwar E, Kosela S, Wibowo W, Zainul R. 2015. Study of Pb (II) biosorption from aqueous solution using immobilized Spirogyra subsalsa biomass. Journal of Chemical and Pharmaceutical Research 7:715-22

202. Desy Kurniawati I, Harmiwati SS, Chaidir Z, Munaf E. Rahmiana Zein, Hermansyah Aziz, Rahadian Zainul. 2015. Biosorption of $\mathrm{Pb}$ (II) from Aqueous Solutions Using Column Method by Lengkeng (Euphoria logan lour) Seed and Shell. Journal of Chemical and Pharmaceutical Research 7:872-7

203. Zainul R, Nurakhbari D, Salim M. Optimization of Spirulina Platensis Culture for Antioxidant Production.https://doi.org/10.17605/OSF.IO/FD6E4

204. Horiza, H., Azhar, M. and Efendi, J. (2017) "EKSTRAKSI DAN KARAKTERISASI INULIN DARI UMBI DAHLIA (Dahlia sp.L) SEGAR DAN DISIMPAN", EKSAKTA: Berkala Ilmiah Bidang MIPA, 18(01), pp. 31-39. doi: https://doi.org/10.24036/eksakta/vol18-iss01/14.

205. Iryani, I., Iswendi, I. and Katrina, I. T. (2017) "UJI AKTIVITAS ANTI DIABETES MELLITUS SENYAWA METABOLIT SEKUNDER FRAKSI AIR DARI BERAS KETAN HITAM ( Oryza satival. Var glutinosa) PADA MENCIT PUTIH", EKSAKTA: Berkala Ilmiah Bidang MIPA, 18(01), pp. 54-60. doi: https://doi.org/10.24036/eksakta/vol18-iss01/17.

206. Suryelita, S., Etika, S. B. and Kurnia, N. S. (2017) "ISOLASI DAN KARAKTERISASI SENYAWA STEROID DARI DAUN CEMARA NATAL (Cupressus funebris Endl.)", EKSAKTA: $\quad$ Berkala Ilmiah Bidang MIPA, 18(01), pp. 86-94. doi: https://doi.org/10.24036/eksakta/vol18-iss01/23.

207. Iskandar, I., Horiza, H. and Fauzi, N. (2017) "EFEKTIVITAS BUBUK BIJI PEPAYA (Carica Papaya Linnaeaus) SEBAGAI LARVASIDA ALAMI TERHADAP KEMATIAN LARVA AEDES AEGYPTY TAHUN 2015”, EKSAKTA: Berkala Ilmiah Bidang MIPA, 18(01), pp. 1218. doi: https://doi.org/10.24036/eksakta/vol18-iss01/12.

208. Ramli, R., Jonuarti, R. and Hartono, A. (2017) “ANALISIS STRUKTUR NANO DARI LAPISAN TIPIS COBALT FERRITE YANG DIPREPARASI DENGAN METODE 
SPUTTERING", EKSAKTA: Berkala Ilmiah Bidang MIPA, 18(01), pp. 46-53. doi: https://doi.org/10.24036/eksakta/vol18-iss01/16.

209. Sanjaya, H. (2017) "DEGRADASI METHYLENE BLUE MENGGUNAKAN KATALIS ZnO-PEG DENGAN METODE FOTOSONOLISIS”, EKSAKTA: Berkala Ilmiah Bidang MIPA, 18(02), pp. 21-29. doi: https://doi.org/10.24036/eksakta/vol18-iss02/45.

210. Ningsih, S. K. (2017) "SINTESIS DAN KARAKTERISASI NANOPARTIKEL ZnO DOPED Cu2+ MELALUI METODA SOL-GEL”, EKSAKTA: Berkala Ilmiah Bidang MIPA, 18(02), pp. 39-51. doi: https://doi.org/10.24036/eksakta/vol18-iss02/51.

211. Saiya, A. (2017) “ANALISIS RESIDU KLORPIRIFOS DALAM SAYURAN KUBIS DENGAN METODE HPLC DI BEBERAPA PASAR TRADISIONAL DI SULAWESI UTARA", EKSAKTA: Berkala Ilmiah Bidang $\quad$ MIPA, $18(02), \quad$ pp. 77-85. doi: https://doi.org/10.24036/eksakta/vol18-iss02/57.

212. Syafei, N. (2017) “ANALISA FENOMENA KOROSI PELAT PIPA BAJA KARBON API 5L-X65 DALAM LARUTAN 250 ML ASAM ASETAT DAN 4750 ML AQUADES PADA KONDISI GAS CO2 DAN H2S JENUH PADA SUHU RUANG", EKSAKTA: Berkala Ilmiah Bidang MIPA, 18(02), pp. 113-120. doi: https://doi.org/10.24036/eksakta/vol18-iss02/63.

213. Tutuarima, T. (2017) "SIFAT FISIK DAN KIMIA MARMALADE JERUK KALAMANSI (Citrus microcarpa) : KAJIAN KONSENTRASI PEKTIN DAN SUKROSA Physical and Chemical Properties of Marmalade Citrus of Calamondin (Citrus microcarpa) : Study of Pectin and Sucrose Concentrations", EKSAKTA: Berkala Ilmiah Bidang MIPA, 18(02), pp. 164-172. doi: https://doi.org/10.24036/eksakta/vol18-iss02/73.

214. Ruswandi, R. (2018) "Determination of Fructose Content resulted by Inulin Hydrolysis with DNS as Oxidizer", EKSAKTA: Berkala Ilmiah Bidang MIPA, 19(1), pp. 14-23. doi: https://doi.org/10.24036/eksakta/vol19-iss1/102.

215. Sanjaya, H. (2018) "DEGRADASI METIL VIOLET MENGGUNAKAN KATALIS ZnOTiO2 SECARA FOTOSONOLISIS”, EKSAKTA: Berkala Ilmiah Bidang MIPA, 19(1), pp. 9199. doi: https://doi.org/10.24036/eksakta/vol19-iss1/131.

216. Hidayani, T. (2018) "GRAFTING POLIPROPILENA DENGAN MALEAT ANHIDRIDA SEBAGAI PENGIKAT SILANG DENGAN INISIATOR BENZOIL PEROKSIDA", EKSAKTA: Berkala Ilmiah Bidang MIPA, 19(1), pp. 56-62. doi: https://doi.org/10.24036/eksakta/vol19-iss1/127.

217. Prabowo, H. (2018) "PENYELIDIKAN KELAYAKAN KIMIA DAN PENYEBARAN CADANGAN PASIR BESI DAERAH TIKU KABUPATEN AGAM UNTUK BAHAN BAKU SEMEN PADA PT. SEMEN PADANG”, EKSAKTA: Berkala Ilmiah Bidang MIPA, 19(1), pp. 39-42. doi: https://doi.org/10.24036/eksakta/vol19-iss1/121.

218. Syafei, N. (2018) "Riset Material ANALISA FENOMENA KOROSI PELAT PIPA BAJA KARBON API 5L-X65 DALAM LARUTAN 7900 ML AIR LAUT DAN 100 ML AMONIAK PADA KONDISI GAS CO2 DAN H2S JENUH PADA SUHU 
RUANG.”, EKSAKTA: Berkala Ilmiah Bidang MIPA, 19(1), pp. 7-13. doi: https://doi.org/10.24036/eksakta/vol19-iss1/83.

219. Parbuntari, H., Prestica, Y., Gunawan, R., Nurman, M. and Adella, F. (2018) "Preliminary Phytochemical Screening (Qualitative Analysis) of Cacao Leaves (Theobroma cacao L.)", EKSAKTA: Berkala Ilmiah Bidang MIPA, 19(2), pp. 40-45. doi: https://doi.org/10.24036/eksakta/vol19-iss2/142.

220. Dinata, M. and Soehardi, F. (2018) "Factor Analysis of Physics Chemistry Waters that Affects Damage Safety Cliff on the Outskirts of River Siak", EKSAKTA: Berkala Ilmiah Bidang MIPA, 19(2), pp. 46-49. doi: https://doi.org/10.24036/eksakta/vol19-iss2/143.

221. Sofyanita, S. and Octaria, Z. (2018) "Fenthion Compound Degradation in the Pesticide Bayleton $500 \mathrm{ec}$ in Sonolysis, Ozonolysis and Sonozolysis with Addition of TiO2anatase", EKSAKTA: Berkala Ilmiah Bidang MIPA, 19(2), pp. 70-79. doi: https://doi.org/10.24036/eksakta/vol19-iss2/153.

222. Harahap, F. and Lubis, L. (2018) "Analysis of Heavy Metals Distribution in the River Town of Hamasaki's Rod Padangsidimpuan”, EKSAKTA: Berkala Ilmiah Bidang MIPA, 19(2), pp. 5056. doi: https://doi.org/10.24036/eksakta/vol19-iss2/149.

223. Syafei, N., Hidayat, D., Emilliano, E. and Men, L. (2018) "Analysis Cracking Corrosion on Carbon Steel Pipes API 5L-X65 In Solution $7700 \mathrm{ml}$ Aquades, $250 \mathrm{ml}$ Acetic Acid and $50 \mathrm{ml}$ Ammonia with Gas CO2 and H2S in Saturation Condition", EKSAKTA: Berkala Ilmiah Bidang MIPA, 19(2), pp. 21-31. doi: https://doi.org/10.24036/eksakta/vol19-iss2/138.

224. Dunne LJ, Manos G. 2010.Adsorption and phase behaviour in nanochannels and nanotubes. Dordrecht ; London: Springer; x, 295 p. p.

225. Khalil M. 2013pemaparan Merkuri Nitrat $\mathrm{Hg}(\mathrm{No} 3) 2$ Dengan Konsentrasi Berbeda Pada Jaringan Hati Benih Ikan Kakap Putih ( Lates Calcarifer Bloch): tinjauan histologi.;133-140:7.

226. Adsorption and adsorbents. New York,: Wiley.

227. Adsorption, aggregation and structure formation in systems of charged particles. pages $\mathrm{cm} \mathrm{p}$.

228. Adsorption [text].

229. Nema PK, Kaur BP, Mujumdar AS. Drying technologies for foods : fundamentals and applications. pages $\mathrm{cm}$ p.

230. Zaikov GE, Bazylak LI, Haghi AK. Functional Polymer Blends and Nanocomposites : A Practical Engineering Approach. xviii, 349 pages p.

231. Cahn SB, Mahan GD, Nadgorny BE. A guide to physics problems. New York: Plenum Press; 1994. 2 bd. p.

232. Gibbs JW. 1931The collected works of J. Willard Gibbs. New York: Longmans;. 2 bind. p.

233. Greiner W, Neise L, Stöcker H. 2000. Thermodynamics and statistical mechanics. New York: Springer-Verlag; xii, 463 s. p.

234. 182. Jancovici B. 1973. Statistical physics and thermodynamics. London: McGraw-Hill; xi, 147 s. p.

235. Kondepudi DK, Prigogine I. 1998.Modern thermodynamics : from heat engines to dissipative structures. Chichester: John Wiley; xx, 486 s. p.

236. Moffatt WG, Pearsall GW, Wulff J. 1964.Structure and properties of materials. N. Y.: John Wiley \& Sons; Bd. 1-. p. 
237. Münster A. 1969.Statistical thermodynamics. Berlin: Springer-Verlag; 2 bd. p.

238. Pauli W, Enz CP. 1973.Pauli lectures on physics. London: MIT Press; 6 bd. p.

239. Teisseyre R, Majewski E. 2001.Earthquake thermodynamics and phase transformations in the earth's interior. San Diego, Calif.: Academic; xxii, 674 s. p.

240. Soller T. 1930.Velocity distribution of secondary electrons from molybdeunm. Minneapolis, 1 , 1212-20 p. p.

241. Nazareth RA, Sreekumar NV, Narayana B. 2001Indirect complexometric determination of mercury(II) using guanidine nitrate as a selective masking agent. Analytical sciences : the international journal of the Japan Society for Analytical Chemistry.;17(11):1339-41.

242. Bohm D, Aller LH. 1947.The electron velocity distribution in gaseous nebulae and stellar envelopes. n.p. 20 p. p.

243. Bhowmik NG. 1991. Velocity distribution at two sites within the southern basin of Lake Michigan. Champaign, Ill.: Illinois State Water Survey; 39 p. p.

244. Bansal RC, Donnet J-B, Stoeckli F. 1988. Active carbon. New York: M. Dekker; xiv, 482 p. p.

245. Zainul, R. (2016, December 18). Design and Modification of Copper Oxide Electrodes for Improving Conversion Coefficient Indoors Lights (PV-Cell) Photocells. https://doi.org/10.31227/osf.io/pgn84

246. Zainul, R. (2016, September 24). Determination of the half-life and the quantum yield of $\mathrm{ZnO}$ semiconductor photocatalyst in humic acid. https://doi.org/10.31227/osf.io/e8a9x

247. Febriani, S. S., Yolanda, T., Arianti, V. A., \& Zainul, R. (2018, September 2). A Review Solid Stated : Principles and Methode. https://doi.org/10.31227/osf.io/7us4x

248. Liza, Y. M., Yasin, R. C., Maidani, S. S., \& Zainul, R. (2018, September 29). SOL GEL : PRINCIPLE AND TECHNIQUE (A REVIEW). https://doi.org/10.31227/osf.io/2cuh8

249. Zainul, R. (2016, November 19). Effect of Temperature and Particle Motion against the ability of $\mathrm{ZnO}$ Semiconductor Photocatalyst in Humic Acid. https://doi.org/10.31227/osf.io/wnygb

250. Dinata, A. A., Rosyadi, A. M., Hamid, S., \& Zainul, R. (2018, August 31). A Review CHEMICAL VAPOR DEPOSITION : PROCESS AND APPLICATION. https://doi.org/10.31227/osf.io/yfeau

251. Ausikaitis JP, Myers AL, Sweed NH, 1985.American Institute of Chemical Engineers. Meeting, American Institute of Chemical Engineers. Group 2 (Diffusional Operations and Processes). Adsorption and ion exchange : recent developments. New York, N.Y.: American Institute of Chemical Engineers; 94 p. p.

252. Aleksandersen Ag. 1992.Æ [sound recording]. Norway: Plateselskapet,

253. Abrams IM, Zwiebel I, Sweed NH, 1975.American Institute of Chemical Engineers. Adsorption/Ion Exchange Program Committee (Area 2F). Adsorption and ion exchange. New York: American Institute of Chemical Engineers; vi, 243 p. p.

254. Gwathmey ES. 1937.Effect of similarity particles on gas kinetic quantities with application to nuclear spins. Lancaster, Pa.,: Lancaster press, inc.; cover-title, p. 944-51. diagrs. 27 x $20 \mathrm{~cm}$. p.

255. Mortimer RG. 2008.Physical chemistry. 3rd ed. Amsterdam ; Boston: Academic Press/Elsevier; xvii, 1395 p. p.

256. Zainul, R. (2016, December 18). Design and Modification of Copper Oxide Electrodes for Improving Conversion Coefficient Indoors Lights (PV-Cell) Photocells. https://doi.org/10.31227/osf.io/pgn84

257. Xu K.2007. Direct modeling for computational fluid dynamics : construction and application of unified gas-kinetic schemes. xvi, 318 pages $\mathrm{p}$. 
258. Norwell, MA. 2001. Adsorption.: Kluwer Academic Publishers. 